\title{
The hedonic valuation of South African wine brands
}

\author{
D. Priilaid* \\ School of Management Studies, University of Cape Town. \\ Private Bag, Rondebosch 7701, Republic of South Africa \\ david.priilaid@uct.ac.za \\ P. van Rensburg \\ Department of Finance and Tax, University of Cape Town, \\ Private Bag, Rondebosch 7701, Republic of South Africa
}

\author{
Received October 2010
}

\begin{abstract}
Working with a set of 35 South African wine brands identified in Priilaid and Van Rensburg (2010a), this study presents two brand valuation techniques that combine non-ordinal wine valuation models with conventional methods of valuation. The first price-premium approach defines brand equity value as the difference between a wine's price and a valuation of its intrinsic worth. The second quality premium approach defines brand equity value as the difference between a wine's intrinsic value and, instead of price, the value of its perceived quality when sampled sighted.

With a set of assumptions regarding consistency in future wine quality, hectorage, price premiums, and sales volumes, brand valuations for each method are calculated as the net present value of the brand premiums paid per unit over the total cases sold. The consequent computations reveal how the price-premium method realises a mean valuation three times greater than the average derived from the alternate quality premium method. This difference is attributed to extreme valuations noted at either end of the price-premium sample, and suggests that this method is perhaps less conservative than perceived quality premium-based valuations. Additionally, the specification of perpetuity is observed to be too extreme. Alternate time scenarios are considered, with a period of ten years posited as perhaps more appropriate to such computations.
\end{abstract}

*To whom all correspondence should be addressed.

\section{Introduction}

From the perspective of economics, hedonics refers to the efficacy, utility or pleasure derived through the consumption of a particular service or good. As such, the hedonic model hypothesizes a market of assorted products with various associated price, quality and characteristic differences and a diversity of consumers, some more willing to pay for certain characteristic bundles than others. In the first hedonic wine analysis, Oczkowski (1994) argued that the price of one bottle of wine relative to another will differ with the additional unit of the different attributes inherent in one bottle relative to another. Approximated through regression analysis, Oczkowski's study demonstrated how the relative price of a particular wine can thus be constituted as the summation of each of the constituent sub-prices as they attached to each of these attributes. In the intervening years, hedonic modelling has gained recognition as a form of wine price analysis (see inter-alia: Nerlove, 1995; Coombris, Lecocq \& Visser, 1997; Schamel, 2000; Schamel \& Anderson, 2001; Thrane, 2004; Van Rensburg \& Priilaid, 2004).

Founded on the above analytical framework, we deploy blind and sighted versions of hedonic quality, to define (1) 'functional' wine brands as those with significantly higher levels of intrinsic quality as proxied by their blind tasting scores, and (2) placebo-type 'symbolic' wine brands as those with statistically significant positive predictive differences between their blind and sighted scores. With a pre-identified set of brands (see Priilaid \& Van Rensburg, 2010a), we thus present and contrast two wine brand valuation techniques that, in conjunction with conventional net present value (NPV) valuation methods, which are based on the use of non-ordinal wine valuation models (see Priilaid \& Van Rensburg, 2006). Emanating from a data-set of 2007 wines, the non-ordinal models applied to this study are developed in Priilaid and Van Rensburg (2010b), and reexplained in this paper.

The first valuation approach is based on a wine's price premium and specifies brand equity per bottle-unit as the difference between a wine's price and a valuation of its intrinsic worth. Such valuations are derived from scores of blind-based wine tasting - a method of assessment devoid of any extrinsic cue bias. Price premiums can generally be regarded as a measure of the extent to which a consumer is willing to pay for a product over and above its intrinsic value, and as such can be considered a measure of customer loyalty. According to David Aaker (1996: 107) the price 
premium approach "may be the best single measure of brand equity available because, in most contexts, any driver of brand equity should affect the price premium".

The second approach defines brand equity per unit as the difference between a wine's intrinsic value and, instead of price, the value of its perceived quality when sampled sighted. For Aaker (1996), perceived quality stands as a proxy for product leadership, an additional component of brand equity, which has been shown to correlate with price premiums, price elasticities and brand usage. Though less finely calibrated a measure than price, a (currency-based) valuation of a branded bottle's perceived quality can also so serve as a measure of consumer preference when juxtaposed against the valuation of a generic wine product of similar quality.

Commonly employed when a brand's utility cannot adequately be explained by the functional attributes at hand, both premium approaches equate with the "value-added" interpretation of brand equity (see Kamakura \& Russell, 1993; Keller, 1993; Erdem \& Swait, 1998; Priilaid \& Van Rensburg, 2010a, inter-alia). These brand perspectives also align well with Keller's (1993: 2) definition of consumer-led brand equity, which he cites as the "consumers' reaction to an element of the marketing mix for the brand in comparison with their reaction to the same marketing mix element attributed to a fictitiously named or unnamed version of the product or service".

By applying discounted cash-flow techniques to both the price and quality premium versions of brand equity, we examine the extent to which a branded wine is trading over and above its value merely as a generic product of equivalent quality. The paper is organised as follows. Section two reviews the relevant literature. Working with data spanning the eight year period between January 2000 and December 2007, section three introduces 35 wine brands that serve as candidates for evaluation. Section four presents the rationale for the combined non-ordinal and NPV-styled valuation methodologies and, thereafter, details the brand premium valuations as calculated per bottle. Where valid, the resultant valuations for the brand as a whole are presented for comparative purposes. Section five concludes.

\section{Literature review}

The last fifty years have witnessed a new species of firm that generates value almost entirely from a variety of intangible assets ranging from technological expertise (for example, Microsoft and Intel), to patents (Servier and Astra Zenica) and brands (Coca-Cola and Pepsi). In an increasingly intelligence-based economy, intangible assets serve as a significant component of the global market and as core constituents of a firm's value. Gerzema and Lebar (2008) indicate that the Nike and Prada brands constitute 84 and 73 percent of the total value of their respective companies. Firms with intangible assets typically display a wide disparity between initial capital invested, and ultimate value realised. Studying financial reports as of February 2008, Colvin (2008) notes for example, that over its corporate life, Microsoft has invested about $\$ 30$ billion worth of financial capital into its business, creating, in the process, about $\$ 221$ billion worth of shareholder value. Google has done even better: its total corporate investment of about $\$ 5$ billion has in turn unlocked value worth about $\$ 124$ billion. Such is this increasing phenomenon of intangible value that Gerzema and Lebar (2008) estimate that the total worth of the 250 most valuable brands stands at roughly $\$ 2,2$ trillion - a figure that in aggregate exceeds the GDP of France. These same authors cite a Fortune Magazine survey indicating that in 2006 some $72 \%$ of the Dow Jones market cap was reportedly due to intangibles (Gerzema \& Lebar, 2008: 10).

As these value estimates continue to verge on hyperbole, it becomes increasingly important that the accounting and financial disciplines seek out sensible and more accurate methods to value intangible assets. This task has however proven difficult. As a survey of the balance sheets of intangible-asset-type firms will attest, conventional accounting practices tend to under-state the worth of these assets or disregard them entirely (Damodaran, 2006). By contrast however, market estimates of such assets appear, at times, to be overstated. Gerzema and Lebar (2008) stated that prior to the internet bubble of 2000 , the S\&P reported intangible values to be as high as $80 \%$. Damodaran (2006) observes that in a good number of consumer product companies, the under-pinning brand name may explain more than half of the firm's value. Weak valuation techniques, he argues, ultimately compromise accounting estimates of profitability (such as return on equity) and ultimately also capital and market estimates (such as price-to-equity ratios). Lev (2003) maintains that the manner in which accountants work with intangibles is neither conservative nor informative. For example, while accounting for researchand-development-related expenses tends to understate earnings in low growth firms - this practice overstates earnings in firms with high growth. In an earlier paper, Lev and Zarowin (1999) argued that revenues from US firms show decreasing levels of stock price correlation, a matter he attributed to the failure to properly account for intangible assets. This decreasing correlation stands in contrast to an earlier study by Barth, Clement, Foster and Kasznik (1998) which, between the period 1991 to 1996, found close correlations between brand values and share prices.

Given the poor job accountants have made of assessing the value of intangible assets, Damodaran (2006) questions whether valuation analysts have done any better. Noting that much of the underpinning valuation information is derived from accounting statements, he concludes not. "The valuation of intangibles assets has suffered from many of the same limitations as the accounting measures. In fact, the pressure on accountants to better reflect the value of intangible assets like brand names on financial statements has provided an impetus to valuation analysts to take a closer look at how they have valued or failed to value these same assets" (Damodaran, 2006: 408).

The literature on holistic brand valuation identifies residual and valuation methods as two related approaches. The residual method seeks to quantify in non-financial terms the intangible components of the brand that remain once intrinsic product characteristics have been 
stripped out. This done, valuation techniques can then be invoked to establish a financial value for these remaining brand-contingent components.

\section{Residual methods}

The residual approach sees brand value only through the lens of various product features, and is underpinned by the view that brand equity is what remains of consumer preferences once physical product effects have been deducted (Keller, 2003). So doing the residual approach analyses a brand by calculating the difference between a consumer's response to (intrinsic) product-related features versus their overall assessment of the brand.

As Keller (2003:490) observes: "A basic tenet behind these (residual) approaches is that it is possible to infer the relative valuation of brands through the observation of consumer preferences and choices if as many sources of measured attribute values are taken into account as possible". Keller notes that the work of Srinivasan (1979), Kamakura and Russell (1993), Swait, Erdem, Louviere and Dubelaar (1993) and Park and Srinivasan (1994), all define brand equity as "the incremental preference over and above that which would result for the product without brand identification" (Keller, 2003: 490). Park and Srinivasan (1994: 271), for example, state that brand equity is "the difference between an individual consumer's overall brand preference and his or her brand preference on the basis of objectively measured product attribute levels." According to Keller, this view implies that brand equity can be estimated by what is left behind once one has subtracted objectively derived physical product preferences from overall preference (including the brand itself).

Using the residual approach to calculate brand equity, Kamakura and Russell (1993) suggest a metric employing the purchase histories of consumers derived from retail check-out scanner data. Working with washing powder brands, these authors thus modelled shopping trolley selections as a combined function of the retail setting, the observable extrinsic features of each available brand, and a residual term to proxy brand equity. A similar method of brand equity estimation is presented by Swait et al. (1993), whose experimental designs control for factors such as brand name and brand image, product cue and various consumer demographic descriptors. Exploring the jean, athletic shoe and deodorant market, these researchers describe the term "equalization price" as the price that equates the total utility a consumer attaches to a brand. Park and Srinivasan (1994) propose a survey-based technique for modelling brand equity whereby brand equity is disaggregated into attribute and non-attribute-based associations. The attribute-based components of brand equity are defined as the difference between subjectively and objectively derived attribute ratings. By contrast, nonattribute based components of brand equity (which can not be objectively measured - for example the image conveyed by BMW vehicles) are defined as the difference between subjectively perceived attribute values and overall preference. After converting these two preference measures into (US) cents, Park and Srinivasan (1994) subtract the attribute-based score from the score for overall brand preference to derive a non-financial individual-level measure of brand equity.

Keller (2003) acknowledges that residual methods may prove useful in interpreting brand equity, but notes that they are most appropriate for brands characterized by a predominance of product (and not market) related attribute associations. (Given the focus on product quality derived from taste sight and smell, for wine studies this is most especially apt.) Because of its inability to distinguish between different market-related attributes, Keller (2003) observes that the residual method is ill suited to the analysis of market related associations. (For wine, such associations would include retail store, volume of sales, level of advertising spend, and so on).

\section{Valuation methods}

Unlike residual methodologies, valuation techniques provide the full expression of (holistic) brand assessment, and most critically, enable a firm to wholly assess its value. This is most especially useful in countries where accounting protocols oblige firms to value their brands and reflect these values in their accounts (Damodaran, 2006).

For accounting purposes, Keller (2003) believes that brand valuation techniques come with certain advantages, namely: (1): they provide a means to increase the aggregate value of a firm; (2): they can assess any hitherto unacknowledged branded assets; (3): as a source of collateral these valuations can prove useful in raising company loans; (4): they can provide a solid framework upon which stakeholders can assess company performance; (5): they can assist in strategic planning, resource planning, and the preparation of marketing plans, and (6): they can be included in the calculation of appropriate third-party brandlicensing fees. Additionally, (7) in South Africa they have also found application for purposes of computing capital gains tax.

In noting the advantages to brand valuation however, Fernandez (2001: 15) observes that this is a complicated exercise: "What makes brand valuation difficult is (1) to understand how the brand creates value for the company and (2) measuring this value correctly".

The literature identifies three potential approaches to valuing brands: the historical cost, the market and the income approach. Of these, the latter appears the most viable with the discounted cash flow (DCF) methodology employed to isolate the effect of the brand name on the firm's cash-flows. Since the effects of the brand name can often, and in varying degrees, be felt throughout a firm, the isolation of brand-contingent cash flows is, however, seldom straight forward.

Damodaran (2006) observes that perhaps the easiest DCF approach is to compare the cash flows of a branded company with those of an otherwise similar (in terms of scale and product) though brand-free company. In effect this comparison allows for the controlling of the brandeffect. So doing any difference between the two cash flows must be attributed to the brand-effect. The present value of 
these cash flows must then be equivalent to the value of the brand under scrutiny. The constraint governing this approach is that of finding a (brand-free) generic firm. For example, locating a generic equivalent to Nike or BMW is likely to prove difficult.

In the light of this difficulty, Damodaran (2006) suggests three variant approaches: (1) the generic operating margin approach, (2) the generic return on capital approach, and (3) the generic excess return approach.

In the instance of the former, we assume that a brand is better positioned to charge higher prices for equivalent products produced by generic firms. Working from this assumption, this approach substitutes the operating margin of the branded firm with operating margin of the generic one. Valuing the branded firm with the lower generic margin will have multiple effects - since lower margins produce lower return on capital - which in turn realise lower growth rates. Thus even a small difference in margin can result in substantial change in value. This change may hence be attributed to the effect of the brand.

In a similar vein, the generic return on capital approach sees the branded firm's return on capital replaced by that of the generic firm. Assuming identical costs of capital for both firms, the key premise to this approach is that the power of the brand name will ultimately realise higher returns on capital. Since a firm's return on capital is the product of post tax operating margin and the sales turnover ratio, higher capital returns can occur in two ways. In the first, the branded company can charge more for the same goods (thus increasing the margin); in the second, it can charge similar prices but drive higher unit volumes (thus increasing sales turnover) (Damodaran, 2006). In this approach the consequent flux in income and sales growth will impact on the value of the firm in question. This change can be equated to the value of the brand itself.

With respect to the generic excess return approach, we define excess returns as the returns on capital minus the costs of capital, and substitute the excess returns earned by the branded company with those earned by that of the generic. This approach has a number of advantages. Firstly, it captures all the value-related effects of changing the return on capital; and secondly, it enables one to set different costs of capital for the branded and generic firms. According to Damodaran (2006) this is more realistic because branded firms generally have less market risk (unlevered betas), more debt capacity, and lower costs of capital.

Two important assumptions underpin these three approaches. Firstly they assume the existence of a generic company and a full and accessible set of financial reports for both firms. (In this sense they don't necessarily have to be publicly traded). Secondly, they assume that the brand name is the only reason for the brand-to-generic differences in margins, capital returns and excess returns. If however the brand name is combined with a number of other firm intangibles, the differential valuation will serve as an aggregate measure of all of these intangibles; and not just of the brand itself. Damodaran (2006) hence argues that this makes the DCF approach more appropriate for products where the only reason for pricing differences is because of the brand name - and not because of quality or service.

In the light of the above, Damodaran (2006) posits that the DCF approach can be better employed in the valuation of firms carrying hedonic-type brands that can easily be calibrated through differences in perceived quality. Thus in the event that we can actually identify those cash-flows legitimately stemming from a wine brand, a modified version of the DCF approach does become workable. This version employs a residual technique which seeks to identify and quantify the intangible brand-related component remaining once intrinsic product characteristics have been stripped out. This done, valuation techniques can be applied to establish a financial value for the remaining brand-contingent component.

\section{Description of data}

For the purposes of brand valuation, we employ a dataset which divides into two sections: (1) eight consecutive years of wine quality metrics and brand names employed to identify statistically significant wine brands, and (2) a dataset of 2007 wine prices ${ }^{1}$.

\section{Data employed for identifying significant wine brands}

Emanating from a dataset of 8225 wines assessed both blind and sighted over an eight year period spanning January 2000 to December 2007, a total of 35 wine brands were selected for valuation. Data for blind scores - a proxy for intrinsic merit - is derived from WINE magazine which employs the five-star or twenty- point scoring system. Working with the sampled data, WINE magazine's mean score is 2,59 stars, with a maximum, minimum and standard deviation of 5,0 and 0,92, respectively. Data for sighted scores - a proxy for the "perceived sighted quality" metric to be evaluated in this study - is derived from (John) Platter's South African Wine Guide which also scores off the five-star system. Of the entire 8225 wines sampled, the mean Platter score is 3,51 stars, with a maximum, minimum and standard deviation of 4,5, 0 and 0,67, respectively. Relative to WINE's blind assessment metrics, its higher mean and lower variability should be noted. Wines containing six or more vintages were considered for brand analysis, and thus from the 8225 wines assembled, some 448 candidate brands were initially identified, potentially qualifying as either functional brands, symbolic ${ }^{2}$ brands, or both.

\footnotetext{
${ }^{1} 2007$ is the base-line year to which all valuations are tied.
}

${ }^{2}$ The two-type functional-to-symbolic terminology employed in this study is consistent with and follows on from the work on SME wine brands by Mowle and Merrilees (2005). It should be noted however that the application of this terminology is not consistently applied across the literature. For example, for those operating within the product-benefit literature (see for example Chitturi, Raghunathan \& Mahajan, 2008), the "symbolic versus functional" brand distinction would be described rather as the difference between "hedonic" and "utilitarian" benefits. Moreover, while in brand theory the term "functional" is used to describe brands with high blind ratings; when applied more generally to foods it may equally denote health improving characteristics such as the presence of certain vitamins or 
Controlling for price and vintage, Priilaid and Van Rensburg (2010a) define a "symbolic" brand as a wine whose sighted-to-blind differential can be statistically attributed to the extrinsic brand cue. The sighted-to-blind differential is derived by subtracting the (blind) WINE magazine score from (sighted) Platter score. Over the entire 8 225-line dataset, the mean average "Platter minus WINE" score is 0,92 stars, with a respective maximum, minimum and standard deviation of $4,5,-2,5$ and 0,90 . By contrast, "functional" brands accrue if, from their blind scores, they present with a statistically significantly higher level of intrinsic quality.

From the initial Priilaid and Van Rensburg (2010a) analysis, 148 functional and 72 symbolic brands are identified; of which the thirty strongest of each appear in Table 1. From these two brand subsets, 35 present as simultaneously functional and symbolic. These appear in the Table 2, and constitute the full sample of brands to be valued in this study. In this table the preponderance of red blends is observed: 12 of the 35 brands identified fall into this cluster. Other key varietal contributions include: sauvignon blanc (5), cabernet sauvignon and chardonnay (4) and pinotage (3).

\section{Data employed for the valuation models}

For the purposes of valuing the 35 selected brands, nonordinal pricing models are developed using a 1358 wine dataset emanating specifically from the 2007 period. This dataset is fully described in Priilaid and Van Rensburg (2010b), and briefly reviewed here. The 1358 wines are extracted from the broader 8225 wine sample noted above; and represent the last of the eight years spanning this broader set of data. In turn these 1358 wines decompose further into two subsets: red wines: $(n=896)$ and white wines $(\mathrm{n}=462)$. Each wine carries an assessment from both WINE magazine (over the period January to December 2007), and the annual Platter wine guide; and in aggregate represent the 2007 red and white wine market in South Africa.

The mean average price for the entire 1358 wine sample is R78,76. The price maximum, minimum and standard deviation for the sample are R730, R8,50 and R58,32 respectively. Within the red wines, pinot noir is on average the most expensive wine per bottle (R108,24), followed by red blends (R96,59), shiraz (R93,88), cabernet sauvignon(R83,34), merlot $(R 73,52)$ and finally pinotage (R70,64). Within the white sample, chardonnay is on average the most expensive wine per bottle (R71,59), followed by white blends (R59,41), sauvignon blanc (R57,81), and lastly chenin blanc (R42,22).

In Priilaid and Van Rensburg (2010b) valuation models are derived by regressing price against 2007 quality metrics from Platter and WINE magazine. Over the 868 red wines tasted, the mean average Platter score is 3,61, with a

proteins. Equally, while the wine literature uses the term "hedonic" assessment to describe a wine-quality assessment derived from a human (as opposed to a machine-based) assessment, readers in the product-benefit school would associate this term with symbolic or aesthetic attributes. maximum, minimum and standard deviation for the sample of 4,5, 1,5 and 0,62 respectively. By comparison to the reds, the mean average Platter score for the 462 white wines tasted is 3,50 , with a maximum, minimum and standard deviation for the sample of $4,5,1,5$ and 0,73 respectively.

Of the red wines assessed in this study, the mean average WINE magazine score is 2,65 , with a maximum, minimum and standard deviation for the sample of 4,5, 1,5 and 0,90 respectively. Equivalent figures for the white wine sample are mean: 2,70, maximum: 5, minimum: 0 , and standard deviation: 0,82 .

\section{Methodology and findings}

\section{Methodology}

As per Damodaran (2006), a brand's worth can be computed as the brand premium multiplied by volumes generated. Placing the implicit NPV calculations momentarily aside, the study at hand seeks explicitly to compare two wine brand valuation techniques, namely those attached to (1) the price-to-intrinsic value premium, and (2) the value of perceived sighted quality-to-intrinsic value premium, respectively. As per Keller (2003), the above two approaches resolve into the following two equations:

either

Value of Brand Premium $=$ Brand price - Intrinsic value .

or

Value of Brand Premium = Value of brand's perceived sighted quality - Intrinsic value.

Assuming that in all instances we are evaluating a legitimate symbolic brand with a predictably consistent difference between its sighted and blind score, ceteris paribus; both the price and quality premium equations carry with them certain requirements.

In the case of the former (the price premium calculation), we should know the price of the wine and be able to ascertain the value of its underlying intrinsic quality. Here it is crucial that each wine presents as a functional brand; with predictably consistent levels of intrinsic quality. Through appropriate price modelling we can hence calculate the worth of that quality-point. In the instance of the 35 wines $^{3}$ qualifying simultaneously as symbolic and functional brands and notified in Table 2, this interim condition is met.

\footnotetext{
${ }^{3}$ In Priilaid and Van Rensburg (2010a) the 37 symbolic brands that failed to qualify as functional brands do not qualify for valuation since they do not present with a statistically consistent intrinsic quality. Thus they fail to qualify for either of the two mooted approaches. In order therefore to qualify as a value-able brand, it is critical that such a brand qualifies simultaneously as both a functional and symbolic brand.
} 
Table 1: The top 30 brand effects identified for blind and sighted-to-blind assessments. This replicates Table 12 in Priilaid and van Rensburg, 2010a. Ratings (in parenthesis) for the blind and sighted-to-blind models are fitted values and are derived in Priilaid and Van Rensburg (2010a). Respectively, they should be noted in relation to the broader blind and sighted-to-blind score means of 2,59 and 0,92 .

\begin{tabular}{|c|c|c|c|c|}
\hline \multicolumn{3}{|c|}{ BLIND MODEL } & \multicolumn{2}{|c|}{ SIGHTED MINUS BLIND MODEL } \\
\hline & Brand and rating & Cultivar & Brand and differential & Cultivar \\
\hline 1 & Kanu Limited Release Wooded $(4,39)$ & chenin blanc & Cabrière $(2,50)$ & pinot noir \\
\hline 2 & Jordan Cobblers Hill $(4,19)$ & red blends & Bouchard Finlayson Missionvale $(2,40)$ & chardonnay \\
\hline 3 & Thelema Reserve $(4,09)$ & merlot & Bouchard Finlayson Sans Barrique $(2,34)$ & chardonnay \\
\hline 4 & Ernie Els Wines $(3,94)$ & red blends & Nederburg Edelrood $(2,15)$ & red blends \\
\hline 5 & Kanonkop $(3,93)$ & pinotage & Diemersdal $(2,11)$ & cabernet \\
\hline 6 & Neil Ellis $(3,86)$ & cabernet & Bilton $(2,10)$ & merlot \\
\hline 7 & De Toren Fusion $V(3,86)$ & red blends & Villiera Traditional Bush Vine $(2,00)$ & sauv-blanc \\
\hline 8 & Mulderbosch Barrel Fermented $(3,83)$ & chardonnay & Welgemeend $(2,00)$ & red blends \\
\hline 9 & Boekenhoutskloof $(3,83)$ & shiraz & Asara $(1,97)$ & red blends \\
\hline 10 & Rustenberg $(3,79)$ & cabernet & Rhebokskloof Grand Reserve $(1,96)$ & chardonnay \\
\hline 11 & Thelema $(3,75)$ & cabernet & Porterville $(1,91)$ & pinotage \\
\hline 12 & Rustenberg $(3,75)$ & red blends & Lushof $(1,88)$ & sauv- blanc \\
\hline 13 & Rust en Vrede $(3,75)$ & red blends & Veenwouden Classic $(1,87)$ & red blends \\
\hline 14 & Kanonkop Paul Sauer $(3,75)$ & red blends & Southern Right $(1,86)$ & sauv-blanc \\
\hline 15 & Rijks $(3,75)$ & chenin blanc & Cordoba $(1,86)$ & merlot \\
\hline 16 & The Sadie Family $(3,72)$ & shiraz & Alto $(1,77)$ & red blends \\
\hline 17 & Saxenburg Private Collection $(3,71)$ & shiraz & Beyerskloof (standard) $(1,76)$ & pinotage \\
\hline 18 & Waterford $(3,67)$ & shiraz & Hoopenburg $(1,71)$ & cabernet \\
\hline 19 & Fleur du Cap Unfiltered $(3,64)$ & chardonnay & Kloovenburg $(1,69)$ & shiraz \\
\hline 20 & Spice Route $(3,61)$ & chenin blanc & Raats $(1,68)$ & chenin blanc \\
\hline 21 & Spice Route flagship wines $(3,61)$ & shiraz & Eikendal $(1,60)$ & merlot \\
\hline 22 & Stellenzicht $(3,61)$ & shiraz & Overgaauw $(1,59)$ & merlot \\
\hline 23 & Morganhof $(3,61)$ & red blends & Kleine Zalze $(1,58)$ & merlot \\
\hline 24 & Vergelegen $(3,60)$ & red blends & Kaapzicht (standard) $(1,58)$ & pinotage \\
\hline 25 & L'Avenir $(3,59)$ & pinotage & Kanu $(1,56)$ & merlot \\
\hline 26 & Moreson $(3,56)$ & pinotage & Meerlust $(1,50)$ & merlot \\
\hline 27 & Hamilton Russell $(3,56)$ & pinot noir & Nederburg $(1,50)$ & cabernet \\
\hline 28 & Glen Carlou $(3,55)$ & shiraz & Kaapzicht Stytler $(1,45)$ & pinotage \\
\hline 29 & Simonsig Merindol $(3,54)$ & shiraz & Beaumont $(1,39)$ & chenin blanc \\
\hline 30 & Graham Beck $(3,53)$ & shiraz & Bouchard Finlayson Kaaimansgat $(1,12)$ & chardonnay \\
\hline
\end{tabular}

Table 2: The 35 selected brands that qualify simultaneously with functional and symbolic/placebo effects. These effects are ranked by ascending order of their predicted average blind score (column 4). In turn, this fitted value is added to column 5's predicted average placebo (sighted-minus blind) score (also fitted); thus imputing the sighted score (col. 6). Both fitted values are derived from the brand-identification models featured in Priilaid and Van Rensburg (2010a).

\section{BRANDS}

\section{Varietal}

\section{2007 Price}

4. Predicted

Blind
Rating

5. Predicted

Placebo

(Sighted - Blind

6. Imputed

Rating

Rating)

Sighted

\begin{tabular}{|c|c|c|c|c|c|c|}
\hline & & & & & & \\
\hline 1 & Porterville & pinotage & $\mathrm{R} \quad 44,75$ & 1,25 & 1,91 & 3,16 \\
\hline 2 & Cabrière & pinot noir & R 128,29 & 1,33 & 2,50 & 3,83 \\
\hline 3 & Bouchard Finlayson Sans Barrique & chardonnay & R 80,00 & 1,46 & 2,34 & 3,80 \\
\hline 4 & Diemersdal & cabernet sauvignon & R 52,00 & 1,64 & 2,11 & 3,75 \\
\hline 5 & Nederburg (standard) & cabernet sauvignon & R 68,49 & 1,67 & 1,50 & 3,17 \\
\hline 6 & Nederburg Edelrood & red blend & $\mathrm{R} \quad 63,88$ & 1,82 & 2,15 & 3,97 \\
\hline 7 & Welgemeend & red blend & R 66,63 & 1,85 & 2,00 & 3,85 \\
\hline 8 & Kleine Zalze & merlot & R 58,53 & 1,92 & 1,58 & 3,50 \\
\hline 9 & Bilton & merlot & R 80,80 & 1,92 & 2,10 & 4,02 \\
\hline 10 & Graham Beck & sauvignon blanc & R 62,58 & 2,76 & 0,50 & 3,26 \\
\hline 11 & Bon Courage & sauvignon blanc & R 32,00 & 2,85 & $-0,30$ & 2,55 \\
\hline
\end{tabular}




\begin{tabular}{|c|c|c|c|c|c|c|}
\hline 12 & Mooiplaas & sauvignon blanc & R 46,85 & 2,97 & 0,16 & 3,13 \\
\hline 13 & Eikendal & cabernet sauvignon & R 81,50 & 3,21 & 0,36 & 3,57 \\
\hline 14 & Raka & red blend & R 72,08 & 3,22 & 0,43 & 3,65 \\
\hline 15 & Avontuur & chardonnay & $\mathrm{R} 70,63$ & 3,32 & 0,16 & 3,48 \\
\hline 16 & Nederburg Private Bin & cabernet sauvignon & R 80,00 & 3,33 & 0,25 & 3,58 \\
\hline 17 & Springfield & sauvignon blanc & $\mathrm{R} \quad 62,93$ & 3,34 & 0,27 & 3,61 \\
\hline 18 & Delheim & pinotage & R 91,98 & 3,36 & 0,29 & 3,65 \\
\hline 19 & Amani & chardonnay & $\mathrm{R} 68,25$ & 3,36 & 0,35 & 3,71 \\
\hline 20 & Diemesfontein & shiraz & $\mathrm{R} 81,51$ & 3,41 & 0,26 & 3,67 \\
\hline 21 & Glen Carlou Tortoise Hill & red blend & $\mathrm{R} 40,00$ & 3,45 & 0,13 & 3,58 \\
\hline 22 & Glen Carlou Grand Classique & red blend & R 120,00 & 3,45 & 0,08 & 3,53 \\
\hline 23 & Hazendal & chenin blanc & $\mathrm{R} 32,00$ & 3,45 & $-0,18$ & 3,27 \\
\hline 24 & Cape Point Vineyards & sauvignon blanc & $\mathrm{R} 80,06$ & 3,48 & 0,43 & 3,91 \\
\hline 25 & Moreson & pinotage & R 39,00 & 3,56 & 0,16 & 3,72 \\
\hline 26 & Vergelegen $V$ & red blend & R 730,00 & 3,60 & 0,85 & 4,45 \\
\hline 27 & Vergelegen Mill Race & red blend & $\mathrm{R} 56,00$ & 3,60 & 0,32 & 3,92 \\
\hline 28 & Morganhof (standard) & red blend & R 165,00 & 3,61 & 0,22 & 3,83 \\
\hline 29 & Morganhof Premier Selection & red blend & $\mathrm{R} \quad 49,15$ & 3,61 & 0,54 & 4,15 \\
\hline 30 & Stellenzicht & shiraz & R 120,10 & 3,61 & 0,36 & 3,97 \\
\hline 31 & Rust en Vrede & red blend & R 270,00 & 3,75 & 0,43 & 4,18 \\
\hline 32 & Mulderbosch Barrel Fermented, & chardonnay & R 155,00 & 3,83 & $-0,03$ & 3,80 \\
\hline 33 & Ernie Els Wines & red blend & R 500,00 & 3,94 & 0,54 & 4,48 \\
\hline 34 & Jordan Cobblers Hill & red blend & R 156,37 & 4,19 & 0,27 & 4,46 \\
\hline 35 & Kanu Limited Release Wooded & chenin blanc & $\mathrm{R} 70,00$ & 4,39 & $-0,35$ & 4,04 \\
\hline
\end{tabular}

In the case of the latter (the quality premium calculation), we should again be able to ascertain the value of a wine's intrinsic quality. Similarly therefore the wine under scrutiny should present as a functional brand with a consistent underpinning of intrinsic quality. In this way we can employ the self-same pricing model to value a specific level of intrinsic quality. Additionally, we should also know the wine's perceived sighted quality and hence be able to model and compute the value of that particular point of quality. Once more, by employing the 35 tabled brands, it is possible to determine both the intrinsic (blind-based) quality of each brand and its perceived sighted quality (that being the intrinsic quality plus the placebo-driven difference between the sighted and blind quality - as proxied by the Platter minus WINE magazine score.) In this way, both conditions are met.

\section{Non-ordinal models}

Implicit in both the above noted price and quality premium equations is the ability to solve independently for the value of a (generic) product of similar intrinsic quality. Additionally the quality premium equation also requires that we value the perceived sighted quality of that same product. As with Van Rensburg and Priilaid (2006), the ordinary least squares (OLS) regression analysis methodology is employed. For pricing purposes these techniques are hereby applied to a dataset of wines emanating from the 2007 period.

So doing, the cross-section of prices (price) is modelled for the similar goods $\mathrm{i}=1 \ldots \mathrm{n}$ as a function of $\mathrm{K}$ consumer desirable $\left(\mathrm{CD}_{\mathrm{k}}\right.$ where $\left.\mathrm{k}=1, \ldots, \mathrm{K}\right)$ characteristics: price $_{\mathrm{i}}=\alpha+\sum_{\mathrm{k}=1}^{\mathrm{K}} \mathrm{b}_{\mathrm{k}} \mathrm{CD}_{\mathrm{k}}+\varepsilon_{\mathrm{i}}$

where:

$\alpha=$ the intercept term as estimated by OLS

$\mathrm{b}=$ the $\mathrm{K}$ slope coefficients as estimated by OLS

$\mathrm{CD}=$ the $\mathrm{K}$ 'consumer desirables'

$\varepsilon \quad=$ a random residual error term following classic assumptions

As in the previously cited study, the classification of the explanatory variables (CD) includes only those that are likely to constitute perceived value for the consumer. Solving, respectively, for the value of a generic non-branded wine and the value of the same product's perceived sighted quality, as explanatory variables (CD), we use the assessment scores from the (blind-based) WINE magazine and the (sight-based) Platter. In both instances, the model disaggregates the price of each wine into value and mispricing components.

The 'value' of each wine, $i$, is then estimated:

$$
\begin{aligned}
& \text { value }_{\mathrm{i}}=\text { price }_{\mathrm{i}}-\varepsilon_{\mathrm{i}} \\
& =\alpha+\sum_{\mathrm{k}=1}^{\mathrm{K}} \mathrm{b}_{\mathrm{k}} \mathrm{CD}_{\mathrm{k}}
\end{aligned}
$$

So doing, the derived fitted values equate to approximations of the wine's value; the difference between value and price reflecting the level of mispricing $\left(\varepsilon_{\mathrm{i}}\right)$ in each instance. The OLS application on the 2007 dataset is presented in Priilaid 
and Van Rensburg (2010b) to estimate the following nonordinal (or dummy-style) valuation models:

$\begin{aligned} \text { DVIQ }_{\mathrm{i}}= & \alpha+\mathrm{b}_{1} \mathrm{cab}_{\mathrm{i}}+\mathrm{b}_{2} \text { merlot }_{\mathrm{i}}+\mathrm{b}_{3} \text { pinot noir }_{\mathrm{i}}+ \\ & \mathrm{b}_{4} \text { shiraz }_{\mathrm{i}}+\mathrm{b}_{5} \text { red blend } \\ & \mathrm{b}_{7} \text { sauv blanc }_{\mathrm{i}}+\mathrm{b}_{6} \text { chardonnay }_{\mathrm{i}}+ \\ & \mathrm{b}_{10} \mathrm{~W}_{8}{ }_{\mathrm{i}}+\mathrm{b}_{19} \mathrm{~W}^{25}{ }_{\mathrm{i}}+\mathrm{b}_{11} \mathrm{~W}^{3}{ }_{\mathrm{i}}+\mathrm{b}_{12} \mathrm{~W}^{35}{ }_{\mathrm{i}}+\mathrm{b}_{13} \mathrm{~W}_{\mathrm{i}}{ }_{\mathrm{i}}+ \\ & \mathrm{b}_{14} \mathrm{~W}^{45}{ }_{\mathrm{i}}+\mathrm{b}_{15} \mathrm{~W}_{\mathrm{i}}^{5}\end{aligned}$

DVPSQ $_{i}=\alpha+b_{1}$ cab $_{i}+b_{2}$ merlot $_{i}+b_{3}$ pinot noir n $_{i}+$ $\mathrm{b}_{4}$ shiraz $_{\mathrm{i}}+\mathrm{b}_{5}$ red blend $_{\mathrm{i}}+\mathrm{b}_{6}$ chardonnay $_{\mathrm{i}}+$ $\mathrm{b}_{7}$ sauv blanc $_{\mathrm{i}}+\mathrm{b}_{8}$ white blend ${ }_{i}+\mathrm{b}_{9} \mathrm{JP}^{05_{i}}$ $+b_{10} \mathrm{JP}^{1}+\mathrm{b}_{11} \mathrm{JP}_{\mathrm{i}}^{2}+\mathrm{b}_{12} \mathrm{JP}^{25}{ }_{\mathrm{i}}+\mathrm{b}_{13} \mathrm{JP}^{3}{ }_{\mathrm{i}}+\mathrm{b}_{14} \mathrm{JP}^{35}{ }_{\mathrm{i}}$ $+\mathrm{b}_{15} \mathrm{JP}_{\mathrm{i}}^{4}+\mathrm{b}_{16} \mathrm{JP}^{45}{ }_{\mathrm{i}}$

where:

$\mathrm{DVIQ}_{\mathrm{i}}$

DVPSQ $_{\mathrm{i}}$

$\mathrm{cab}$

merlot

$=1$ if wine $\mathrm{i}$ is a merlot; 0 if otherwise.

pinot noir $\quad=1$ if wine $\mathrm{i}$ is a pinot noir; 0 if otherwise.

shiraz $=$ if wine $\mathrm{i}$ is a shiraz; 0 if otherwise.

red blend $\quad=1$ if wine $\mathrm{i}$ is a red blend; 0 if otherwise.

chardonnay $=1$ if wine $\mathrm{i}$ is a chardonnay; 0 if otherwise.

sauv blanc $\quad=1$ if wine $\mathrm{i}$ is a sauvignon blanc; 0 if otherwise.

white blend $=1$ if wine $\mathrm{i}$ is a white blend; 0 if otherwise.

$\mathrm{JP}^{05}$

$\mathrm{JP}^{1}$

$\mathrm{JP}^{2}$

$\mathrm{JP}^{25}$

$\mathrm{JP}^{3}$

$\mathrm{JP}^{35}$

$\mathrm{W}^{2}$
$\mathrm{W}^{25}$
$\mathrm{W}^{3}$
$\mathrm{JP}^{45}$
$\mathrm{JP}^{4}$
$\mathrm{W}^{1}$
$\mathrm{W}^{35}$
$\mathrm{W}^{4}$
$\mathrm{W}^{45}$
$\mathrm{W}^{5}$
$=1$ if wine $\mathrm{i}$ obtained 2,5 WINE magazine stars; 0 if otherwise.
$=1$ if wine $\mathrm{i}$ obtained 3 WINE magazine stars; 0 if otherwise.
$=1$ if wine $\mathrm{i}$ obtained 4,5 John Platter stars; 0 if otherwise.
$=1$ if wine $\mathrm{i}$ obtained 4 John Platter stars; 0 if otherwise.
$=1$ if wine $\mathrm{i}$ obtained 1 WINE magazine stars; 0 if otherwise.
$=1$ if wine $\mathrm{i}$ obtained 3,5 WINE magazine stars; 0 if otherwise.
$=1$ if wine $\mathrm{i}$ obtained 4 WINE magazine stars; 0 if otherwise.
$=1$ if wine $\mathrm{i}$ obtained 4,5 WINE magazine stars; 0 if otherwise.
$=1$ if wine $\mathrm{i}$ obtained 5 WINE magazine stars; 0 if otherwise.

As a consequence of the interim methodology outlined above, non-ordinal valuation models are derived for blind and sighted valuations of red and white wines, and these appear in the Table 3. As can be noted in the equations above, no bottle cues or supply side factors are accounted for other than those implicit in the (sighted) ratings themselves. This is in line with the consumer-facing logic of hedonic modelling outlined in Priilaid and Van Rensburg (2006) which argued that cues like vintage, and estate reputation, if not captured in quality metrics themselves, were if little relevance in the eyes of the consumer. Aside from the application of varietal variables, therefore, the red and white models employed in this study are thus styled upon either sighted or blind quality ratings and nothing else. Treating each wine on its individual merit, earlier studies demonstrate the bias-reducing effect of employing dummy variables instead of ordinary linear calibrations. This dummy-style approach thereby addresses the central flaw in the linear modelling technique: that it cannot adequately price wines of exceptional quality (see Priilaid \& Van Rensburg, 2006). Figures I and II depict the scattergrams of the consequent blind/generic and sighted valuation models for the white wine sample. Note how the adjusted $R^{2}$ is higher for sighted ratings rather than blind. This can be attributed to the presence of the sighted price cue which enforces a tighter correlation between price and sighted, rather than blind scores.

Matched together with the appropriate price-data, the derived non-ordinal blind and sighted valuation models can be used to solve for the brand premium attendant with either the price-premium or the quality premium methods of brand valuation - as in equations (1) and (2) cited earlier. 
Table 3: Red and white wines 2007: estimated dummy model regressions for blind and sighted metrics. Note: significant $t$-stat figures and their respective coefficients are cited in bold. Sighted valuations attract higher adjusted $\mathrm{R}^{2}$ values than blind ones.

\begin{tabular}{|c|c|c|}
\hline $\begin{array}{r}\text { Variable } \\
\end{array}$ & Coefficient & t Statistic \\
\hline \multicolumn{3}{|c|}{ Red wines: Dummy Model for Blind (WINE Mag) assessments only (Adj, $\left.\mathrm{R}^{2}: 8,83 \%, \mathrm{~F}: 7,67(p=0,00), \mathrm{n}=896.\right)$} \\
\hline Constant & 42,94 & 4,90 \\
\hline shiraz & 20,56 & 3,49 \\
\hline cabernet sauvignon & 6,41 & 1,13 \\
\hline merlot & 6,40 & 1,20 \\
\hline pinot noir & 34,25 & 2,38 \\
\hline red blends & 21,64 & 3,73 \\
\hline WINE Magazine 1 star & 15,85 & 1,60 \\
\hline WINE Magazine 2 stars & 15,17 & 1,73 \\
\hline WINE Magazine 2,5 stars & 16,91 & 1,93 \\
\hline WINE Magazine 3 stars & 34,53 & 3,98 \\
\hline WINE Magazine 3,5 stars & 57,69 & 4,93 \\
\hline WINE Magazine 4 stars & 55,03 & 4,97 \\
\hline WINE Magazine 4,5 stars & 89,91 & 2,82 \\
\hline WINE Magazine 5 stars & 190,91 & 23,14 \\
\hline \multicolumn{3}{|c|}{ Red Wines regression: Dummy Model for Sighted (Platter) assessments only (Adj, $\left.\mathrm{R}^{2}: 33,15 \%, \mathrm{~F}: 41,36(p=0,00), \mathrm{n}=896.\right)$} \\
\hline Constant & $\mathbf{3 8 , 5 4}$ & 6,10 \\
\hline shiraz & 14,48 & 2,97 \\
\hline cabernet sauvignon & 4,73 & 1,12 \\
\hline merlot & 5,58 & 1,30 \\
\hline pinot noir & 30,27 & 2,69 \\
\hline red blends & 17,09 & $\mathbf{3 , 8 0}$ \\
\hline Platter 2 stars & $-11,73$ & $-1,52$ \\
\hline Platter 2,5 stars & $-6,21$ & $-0,88$ \\
\hline Platter 3 stars & 7,31 & 1,00 \\
\hline Platter 3,5 stars & 23,28 & 3,39 \\
\hline Platter 4 stars & 44,73 & 6,38 \\
\hline Platter 4,5 stars & 118,95 & 11,02 \\
\hline \multicolumn{3}{|c|}{ White wines: Dummy Model for Blind (WINE Mag) assessments only (Adj, $\left.\mathrm{R}^{2}: 28,13 \%, \mathrm{~F}: 17,40(p=0,00), \mathrm{n}=462.\right)$} \\
\hline Constant & 45,26 & 2,71 \\
\hline chardonnay & 32,26 & 8,80 \\
\hline sauvignon blanc & 19,06 & 6,59 \\
\hline white blends & 14,20 & $\mathbf{3 , 0 3}$ \\
\hline WINE Magazine 1 star & $-20,94$ & $-1,23$ \\
\hline WINE Magazine 2 stars & $-16,18$ & $-0,96$ \\
\hline WINE Magazine 2,5 stars & $-11,43$ & $-0,67$ \\
\hline WINE Magazine 3 stars & $-4,78$ & $-0,28$ \\
\hline WINE Magazine 3,5 stars & 7,18 & 0,41 \\
\hline WINE Magazine 4 stars & 20,91 & 1,18 \\
\hline WINE Magazine 4,5 stars & 66,51 & 1,95 \\
\hline WINE Magazine 5 stars & 92,24 & 1,35 \\
\hline \multicolumn{3}{|c|}{ White wines regression: Dummy Model for Sighted (Platter) assessments only (Adj, $\left.\mathrm{R}^{2}: 44,39 \%, \mathrm{~F}: 34,45(p=0,00), \mathrm{n}=462.\right)$} \\
\hline Constant & $\mathbf{2 0 , 2 2}$ & 6,79 \\
\hline chardonnay & 15,49 & 4,43 \\
\hline sauvignon blanc & 2,40 & 0,77 \\
\hline white blends & 11,87 & 2,78 \\
\hline Platter 0,5 stars & 2,78 & 0,94 \\
\hline Platter 1 star & $-3,91$ & $-0,95$ \\
\hline Platter 2 stars & $-1,79$ & $-0,44$ \\
\hline Platter 2,5 stars & 8,49 & 1,93 \\
\hline Platter 3 stars & 9,16 & 3,16 \\
\hline Platter 3,5 stars & 25,14 & 8,12 \\
\hline Platter 4 stars & 45,48 & 12,69 \\
\hline Platter 4,5 stars & 72,57 & $\mathbf{9 , 8 6}$ \\
\hline
\end{tabular}




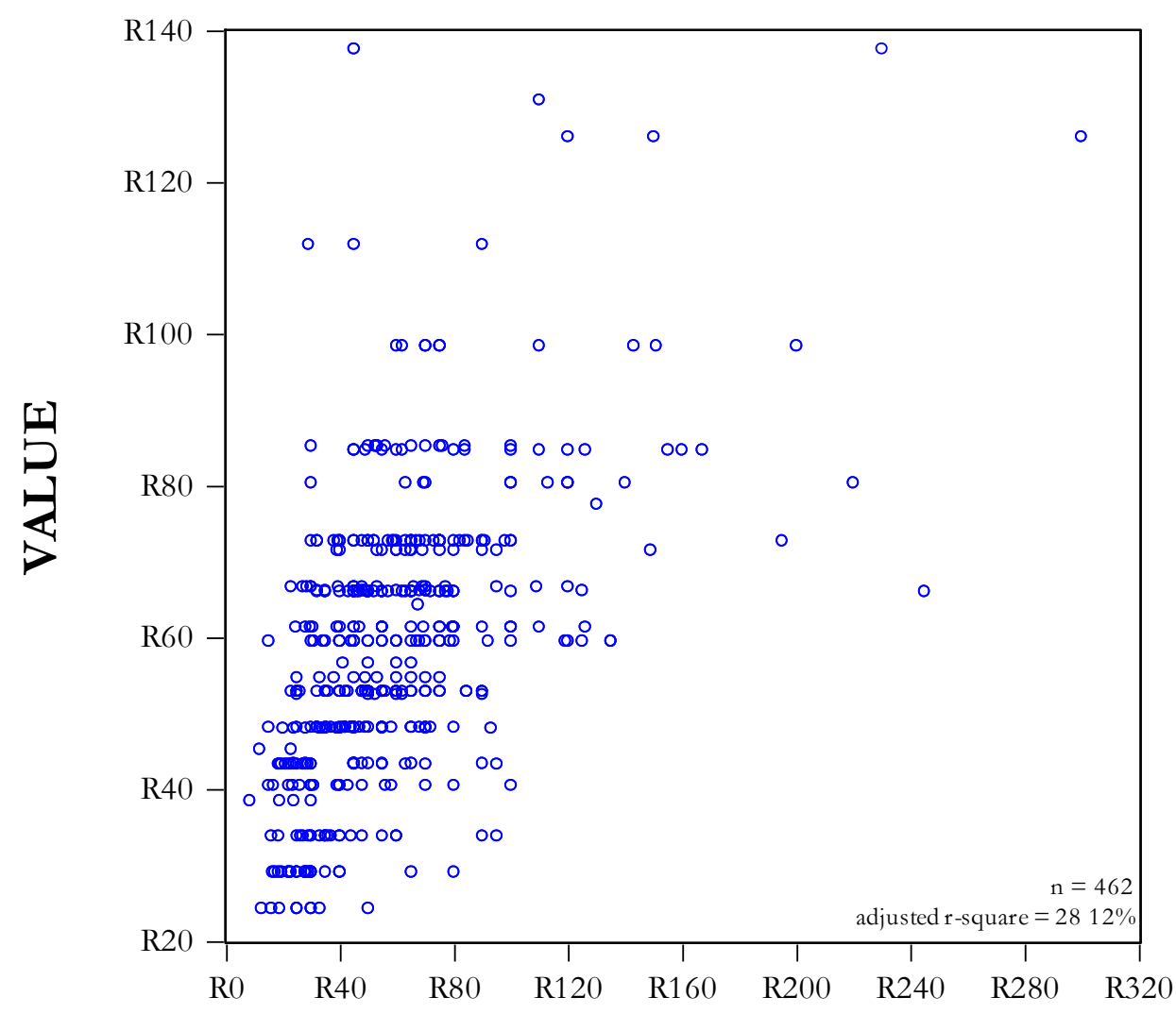

\section{PRICE}

Figure 1: White wines 2007: price versus value: based on blind tastings. This scattergram is derived from the model presented in Table 3. Blind tastings contain no cue bias and are thus reliable predictors of generic 'no-name brand' value.

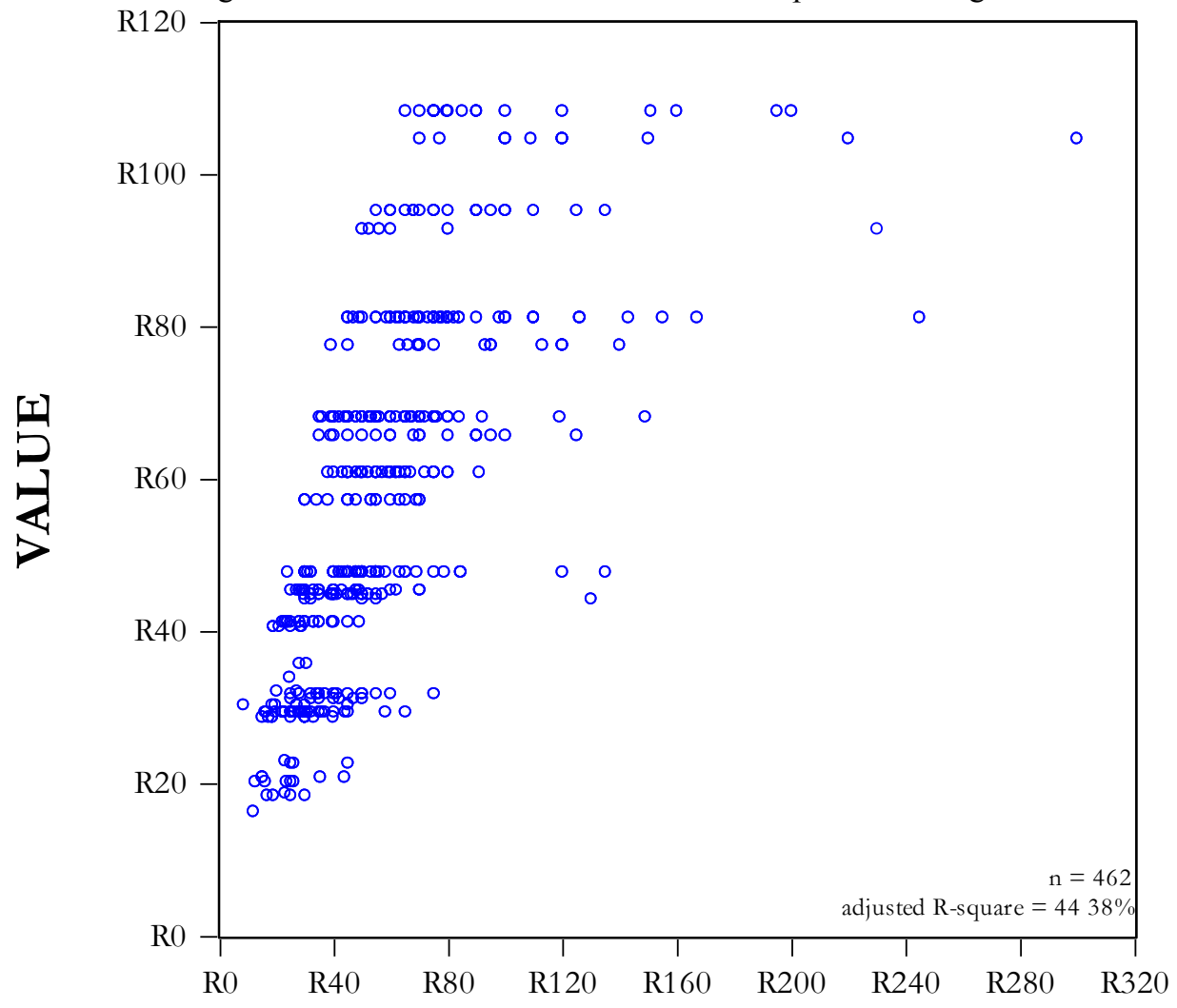

PRICE

Figure 2: White wines 2007: price versus value: based on sighted tastings. This scattergram is derived from Table 3's sighted model. Such tastings contain brand-cue bias and are thus invoked as predictors of brand (as opposed to generic) value. 
Furthermore, when using the price premium method, from equation 4 we should note (a) that the fitted values of the blind-based regression models (featured in Table 3) are taken as an estimate of intrinsic value (DVIQ) and (b) that the individual pricing deviations from this relationship of best fit ( $\varepsilon_{\text {blind }}$ for each wine) represent the magnitude of the relative mispricing in the blind pricing model. For the dummy valuation of intrinsic quality for each wine, this implies that: DVIQ $=$ price $-\varepsilon_{\text {blind }} \ldots$ and hence that price DVIQ $=\varepsilon_{\text {blind }}$. Since this last expression is merely a reconfiguration of equation (1), accordingly, we can say that when using the price-premium method, the brand premium constitutes no more than the magnitude of the blind model's mispricing, in other words, the error term $\left(\varepsilon_{\text {blind }}\right)$. Applied to the quality premium method, an equivalent manipulation of equation 4 reveals that the quality-based brand premium equates to the difference between the blind and the sighted error terms: $\varepsilon_{\text {blind }}-\varepsilon_{\text {sighted }}$. Note that price will have a higher volatility than the model's predicted values in both cases, and given that mispricings of both approaches are likely to be correlated, $\varepsilon_{\text {blind }}-\varepsilon_{\text {sighted }}$ is expected to have a lower volatility than $\varepsilon_{\text {blind. }}$.

\section{Net present value}

Applying conventional financial techniques, we can now derive the net present value (NPV) of each of the wine brands under consideration, hence making methodological comparisons possible. The implicit NPV calculation requires that we multiply each bottle's brand premium by the annual volume generated, and apply a discount rate, K, and (where feasible) a growth rate, g, so as to satisfy the following perpetuity equation for $\mathrm{P}_{0}$, the total brand value:

$\mathrm{P}_{0}=\mathrm{CF}_{1} /(\mathrm{K}-\mathrm{g})$

(Gordon \& Shapiro, 1956)

where:

$\mathrm{CF}_{0}=$ the current Cash Flow (being the brand premium multiplied by the current volume)

$\mathrm{g}=$ the current growth rate of $\mathrm{CF}_{0}$

$\mathrm{K}=$ the adjusted discount rate.

Assuming $\mathrm{CF}_{1}=\mathrm{CF}_{0}(1+\mathrm{g})$, we get:

$\mathrm{P}_{0}=\mathrm{CF}_{0}(1+\mathrm{g}) /(\mathrm{K}-\mathrm{g})$

Restated, K, the discount rate, is the opportunity cost which shareholders forgo by investing in a specific company. A common solution to $\mathrm{K}$ is derived from the capital asset pricing model (CAPM), a pricing model that seeks to extrapolate the expected risk premium of any given company. Developed in mid-1960s (see Sharpe, 1964; Lintner, 1965), the CAPM assumes that there are no transaction costs and that all relevant information is publicly available and therefore fully priced into the market. So doing it concludes, perhaps heroically, that investors hold portfolios that include every available market-traded asset and that the risk of any single investment is the risk added to this market portfolio. The model gives us the following equation for $\mathrm{K}$ :
$\mathrm{K}=\mathrm{R}_{\mathrm{f}}+\mathrm{B}\left(\mathrm{R}_{\mathrm{m}}-\mathrm{R}_{\mathrm{f}}\right)$

Reading from the above, we note three critical components:

1. $\mathrm{R}_{\mathrm{f}}$, the marked-to-market risk free interest rate

2. $B$; the beta of the company under scrutiny and

3. $\left(\mathrm{R}_{\mathrm{m}}-\mathrm{R}_{\mathrm{f}}\right)$, the expected premium of the market over and above the risk free interest rate.

Each is described more fully below.

1. $\mathrm{R}_{\mathrm{f}}$, the marked-to-market risk free interest rate, can be derived by employing the yield of ten-year long term government bonds. Locally, such bonds are freely traded via the Bond Exchange of South Africa; and a yield curve is created that runs through these bonds. In this study we employ a risk free rate $\left(\mathrm{R}_{\mathrm{f}}\right)$ of $8,00 \%$. This figure is cited as of March 2007 by the National Regulator of South Africa (NRSA), who, so doing, in turn cite figures from the Reserve Bank of South Africa. (The cited NRSA figure was published on 19 November 2008).

2. The beta $(B)$ of the company under scrutiny is a proxy for undiversifiable risk. Asset pricing theory argues that this form of risk, which cannot costlessly be diversified away, is rewarded with a premium.

Since most South African wines emanate from unlisted companies, some discussion around the selection of the beta is appropriate. Simon Howie, a senior executive at Investec bank, noted that it is best not to infer a beta value from any observed data; since it is too specific to a company (Simon Howie, pers. comm., 2009.) In the instance of the South African wine industry, the only listed companies, Distell and KWV, are, for a number of reasons, viewed as market-defensive and therefore attract lower betas. Such reasons include that (1) they carry a diversity of brands, (2) they usually buy in their produce (and thus are less reliant on non-controllable factors such as own supply and weather), (3) they are conservatively managed with little debt (debt levels and betas correlate positively), and (4) their shares are thinly traded. However one could also argue that since smaller wine companies are vulnerable to a limited product range and other uncontrollable variables, they warrant higher betas. Conversely by showing dependability of earnings and premium prices charged, in such instances it could be argued that the risk is low and thus a lower beta is applicable. In lieu of these complications, Howie notes that seasoned investment analysts tend to call on past experience and intuition to add an additional risk premium, rather than trying to infer a beta. All this said the most defendable route is to use the market beta as any deviation is so subjective (Simon Howie, pers. comm., 2009.) For the purposes of this research therefore, an average of the Distell and KWV 2007 betas (0,93 and 0,70, respectively) is applied, yielding a figure of 0,815. (Relevant figures are cited from the Stock Exchange Handbook: June September 2007, see Oldert 2007: 33). 
3. The market premium $\left(\mathrm{R}_{\mathrm{m}}-\mathrm{R}_{\mathrm{f}}\right)$, can be derived from the expected rate of return on the local market less the risk free interest rate. While this figure tends to fluctuate in the short term, over longer periods, this figure is less volatile. The figure used in this research $(5,50 \%)$ is extracted from study of Firer and Staunton (2002: 63), who summarise the real annual return of South African equity and bonds from 1900 to 2001. Using the geometric mean, they calculate that over this period, the respective average return on equity and bonds is $7,0 \%$ and $1,5 \%$. The difference - or equity risk premium is thus $5,5 \%$, a figure widely employed in the finance industry for valuation purposes (Simon Howie, pers. comm., 2003).

Subject to a set of assumptions including a consistency in future wine quality, hectorage, price points and sales volumes, final brand valuations for each method are treated in the same vein as perpetuities, with an indefinite stream of future dividends. Assuming hectorage and sales volumes to be constant, we can, in the majority, assign growth to zero, hence $g=0$. Thus

$\mathrm{P}_{0}=\mathrm{CF}_{0}(1+\mathrm{g}) /(\mathrm{K}-\mathrm{g})$

becomes:

$\mathrm{P}_{0}=\mathrm{CF}_{0} / \mathrm{K}$

With respect to either the price or quality premium variations of brand valuation, having hence solved for $\mathrm{CF}_{0}$ (the brand premium $\mathrm{x}$ current volume), and inserted the appropriately adjusted discount rate, $\mathrm{K}$, the full brand value can now be computed.

If however we replace the assumption governing the perpetuity calculation to one where we calculate instead brand-specific revenues over a limited period of $T$ years, the equation for $\mathrm{P}_{0}$, the present value of the brand, becomes:

$\mathrm{P}_{0}=\sum_{\mathrm{t}=1}^{\mathrm{T}}\left(\mathrm{CF}_{\mathrm{t}} /\left(1+\mathrm{R}_{\mathrm{t}}\right)^{\mathrm{t}}\right)$

(Brealey \& Meyers, 2000: 36)

where:

$\mathrm{t} \quad=$ the given year

$\mathrm{CF}_{\mathrm{t}}=$ the brand premium $\mathrm{x}$ the volume contingent to year $\mathrm{t}$,

$\mathrm{R}=$ the opportunity cost of investing money for one year, in our instance $\mathrm{K}$, the already cited adjusted discount rate.

\section{Findings}

With interim valuation results for the price and sighted quality premium styles of analyses depicted respectively in Tables 4 and 5, a number of observations are appropriate.

1. Not all brands yield positive valuations. On completion of the interim (or partial) brand premiumper-bottle valuations, we note that of the 35 candidate brands, within the price and quality premium style of analyses, respectively, 14 and 11 different brands emerge with positive valuations - that is to say with either price or sight-based valuations greater than their generic versions. The remaining brands carry negative premium valuations. The positive valuations are of import to wine producers since these can be reported in the sale of a wine business, potentially at least. The negative valuations are of significance to consumers, since they represent an intrinsic value premium relative to either their respective price or (sighted) quality-based valuations, or both. These negative brands are, however, not the focus of this paper, and not included in the results.

2. Flagship brands predominate positive valuations. Within the price premium analysis closer scrutiny of the 14 positive brand valuations reveals the extent to which red blends dominate the line-up. Six out of 14 are red blends, with an average brand premium per bottle of R197,25. Two sauvignon blancs and chardonnays are identified (average R5,49 and R38,80, respectively) as is one merlot $(\mathrm{R} 16,29)$, pinot noir $(\mathrm{R} 35,59)$ shiraz $(\mathrm{R} 13,06)$ and cabernet sauvignon $(\mathrm{R} 3,63)$. All six of the red blends can be considered "flag ship" brands: Vergelegen $V$ (premium R607,73, price R730), Ernie Els (premium R380,39, price R500), Rust en Vrede (premium R147,73, price R270), Morganhof Premier Selection (premium R45,39, price R165), Jordan Cobbler's Hill (premium R1,88, price R156.37) and Glen Carlou Grand Classique (premium R0,39, price R120).

A similar picture emerges in the quality premium analysis. Of the 11 positive brands again, six are red blends, with an average brand premium per bottle of R37,26. Two merlots are identified (average R13,62) as is one chardonnay (R22,23), pinot noir (R20,84) and cabernet sauvignon (R22,23). Here four of the six red blends can be considered "flag ship" brands: Ernie Els (premium R54,97), Morganhof Premier Selection (premium R54,97), Vergelegen $V$ (premium R52,31), and Jordan Cobbler's Hill (premium R20,09). These four also found in the price premium analysis. The remaining two red blends are: Welgemeend (premium R20,61), and Nederburg Edelrood (premium R20,61). 
Table 4: Brand premium valuation per bottle as measured by the Price-Premium method. This is the difference between price (2007) and intrinsic quality valuations (in Rands). We calculate these intrinsic/ "no-name brand" valuations per bottle using the appropriate intrinsic values (in col.3), as per the pricing models presented in Table 3. These valuations appear thus in column 4 above. Column 6 presents the brand premium valuation by calculating the difference between columns 5 and 4 , and the table is ranked by descending order of this variable.

\section{BRAND PREMIUMS PER BOTTLE \\ VIA DIFFERENCE IN PRICE AND INTRINSIC QUALITY VALUATIONS}

\begin{tabular}{|c|c|c|c|c|c|}
\hline 1. Brands & 2. Varietal & $\begin{array}{c}\text { 3. } \\
\text { Blind / Intrinsic Rating }\end{array}$ & $\begin{array}{c}4 . \\
\text { Intrinsic Value } \\
\text { Per Bottle }\end{array}$ & $\begin{array}{c}5 . \\
2007 \text { Price }\end{array}$ & $\begin{array}{l}\text { 6. Price minus Intrinsic } \\
=\text { Brand Premium }\end{array}$ \\
\hline 1. Vergelegen $V$ & red blend & 3,5 & 122,27 & 730,00 & 607,73 \\
\hline 2. Ernie Els Wines & red blend & 4 & 119,61 & 500,00 & 380,39 \\
\hline 3. Rust en Vrede & red blend & 3,5 & 122,27 & 270,00 & 147,73 \\
\hline 4. Mulderbosch Barrel Fermented. & chardonnay & 4 & 98,43 & 155,00 & 56,57 \\
\hline 5. Morganhof Premier Selection & red blend & 4 & 119,61 & 165,00 & 45,39 \\
\hline 6. Cabrière & pinot noir & 1,5 & 92,70 & 128,29 & 35,59 \\
\hline $\begin{array}{l}\text { 7. Bouchard Finlayson Sans } \\
\text { Barrique }\end{array}$ & chardonnay & 1,5 & 58,96 & 80,00 & 21,04 \\
\hline 8. Bilton & merlot & 2,0 & 64,51 & 80,80 & 16,29 \\
\hline 9. Stellenzicht & shiraz & 3,5 & 107,04 & 120,10 & 13,06 \\
\hline 10. Cape Point Vineyards & sauvignon blanc & 3,5 & 72,13 & 80,06 & 7,93 \\
\hline 11. Nederburg straight & cabernet sauvignon & 1,5 & 64,86 & 68,49 & 3,63 \\
\hline 12. Graham Beck & sauvignon blanc & 3 & 59,54 & 62,58 & 3,04 \\
\hline 13. Jordan Cobblers Hill & red blend & 4,5 & 154,49 & 156,37 & 1,88 \\
\hline 14. Glen Carlou Grand Classique & red blend & 4 & 119,61 & 120,00 & 0,39 \\
\hline 15. Eikendal & cabernet sauvignon & 3,0 & 83,88 & 81,50 & $-2,38$ \\
\hline 16. Kleine Zalze & merlot & 2,0 & 64,51 & 58,53 & $-5,98$ \\
\hline 17. Delheim & pinotage & 3,5 & 100,63 & 91,98 & $-8,65$ \\
\hline 18. Springfield & sauvignon blanc & 3,5 & 72,13 & 62,93 & $-9,20$ \\
\hline 19. Mooiplaas & sauvignon blanc & 3 & 59,54 & 46,85 & $-12,69$ \\
\hline 20. Diemersdal & cabernet sauvignon & 1,5 & 64,86 & 52,00 & $-12,86$ \\
\hline 21. Welgemeend & red blend & 2,0 & 79,75 & 66,63 & $-13,12$ \\
\hline 22. Porterville & pinotage & 1,0 & 58,79 & 44,75 & $-14,04$ \\
\hline 23. Avontuur & chardonnay & 3,5 & 84,70 & 70,63 & $-14,07$ \\
\hline 24. Nederburg Edelrood & red blend & 2,0 & 79,75 & 63,88 & $-15,87$ \\
\hline 25. Amani & chardonnay & 3,5 & 84,70 & 68,25 & $-16,45$ \\
\hline 26. Hazendal & chenin blanc & 3,5 & 52,44 & 32,00 & $-20,44$ \\
\hline 27. Diemesfontein & shiraz & 3,5 & 107,04 & 81,51 & $-25,53$ \\
\hline 28. Raka & red blend & 3,0 & 99,11 & 72,08 & $-27,03$ \\
\hline 29. Nederberg Private Bin & cabernet sauvignon & 3,5 & 107,04 & 80,00 & $-27,04$ \\
\hline 30. Bon Courage & sauvignon blanc & 3 & 59,54 & 32,00 & $-27,54$ \\
\hline 31. Kanu Limited Release Wooded & chenin blanc & 4,5 & 111,77 & 70,00 & $-41,77$ \\
\hline 32. Morganhof straight reds & red blend & 3,0 & 99,11 & 49,15 & $-49,96$ \\
\hline 33. Moreson Pinehurst & pinotage & 3,5 & 100,63 & 39,00 & $-61,63$ \\
\hline 34. Vergelegen Mill Race & red blend & 3,5 & 122,27 & 56,00 & $-66,27$ \\
\hline 35. Glen Carlou Tortoise Hill & red blend & 3,5 & 122,27 & 40,00 & $-82,27$ \\
\hline Mean & & 3,06 & 91,16 & 113,61 & 22,45 \\
\hline Standard Deviation & & 0,92 & 25,65 & 136,60 & 127,16 \\
\hline
\end{tabular}


Table 5: Brand premium valuation per bottle as measured by the Quality Premium method. This is the difference between the sighted and intrinsic quality valuations (in Rands). Using the appropriate sighted and blind scores (col. 4 and 5), we calculate their predicted sighted and blind-based valuations per bottle as per the pricing models presented in Table 3 . These valuations appear above in columns 6 and 7. Column 8 presents the brand premium valuation by calculating the difference between columns 6 and 7, and the table is ranked by descending order of this variable.

\section{BRAND PREMIUMS PER BOTTLE
VIA DIFFERENCE BETWEEN SIGHTED AND INTRINSIC QUALITY VALUATIONS}

\begin{tabular}{|c|c|c|c|c|c|c|c|}
\hline 1. Brands & 2. Varietal & $\begin{array}{c}3 . \\
2007 \\
\text { Price }\end{array}$ & 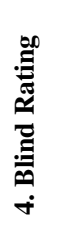 & 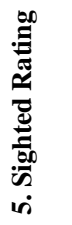 & $\begin{array}{c}6 . \\
\text { Intrinsic Value } \\
\text { per } \\
\text { Bottle }\end{array}$ & $\begin{array}{l}\text { 7. Sighted Value per } \\
\text { Bottle }\end{array}$ & $\begin{array}{l}\text { 8. Sighted } \\
\text { minus } \\
\text { Intrinsic } \\
=\text { Brand } \\
\text { Premium }\end{array}$ \\
\hline 1. Ernie Els Wines & red blend & 500,00 & 4 & 4,5 & 119,61 & 174,58 & 54,97 \\
\hline 2. Morganhof Premier Selection & red blend & 165,00 & 4 & 4,5 & 119,61 & 174,58 & 54,97 \\
\hline 3. Vergelegen $V$ & red blend & 730,00 & 3,5 & 4,5 & 122,27 & 174,58 & 52,31 \\
\hline 4. Bilton & merlot & 80,80 & 2,0 & 4 & 64,51 & 88,85 & 24,34 \\
\hline 5. Bouchard Finlayson Sans Barrique & chardonnay & 80,00 & 1,5 & 4 & 58,96 & 81,19 & 22,23 \\
\hline 6. Cabrière & pinot noir & 128,29 & 1,5 & 4 & 92,70 & 113,54 & 20,84 \\
\hline 7. Nederburg Edelrood & red blend & 63,88 & 2,0 & 4 & 79,75 & 100,36 & 20,61 \\
\hline 8. Welgemeend & red blend & 66,63 & 2,0 & 4 & 79,75 & 100,36 & 20,61 \\
\hline 9. Jordan Cobblers Hill & red blend & 156,37 & 4,5 & 4,5 & 154,49 & 174,58 & 20,09 \\
\hline 10. Kleine Zalze & merlot & 58,53 & 2,0 & 3,5 & 64,51 & 67,40 & 2,89 \\
\hline 11. Diemersdal & cabernet sauvignon & 52,00 & 1,5 & 3,5 & 64,86 & 66,55 & 1,69 \\
\hline 12. Amani & chardonnay & 68,25 & 3,5 & 4 & 84,70 & 81,19 & $-3,51$ \\
\hline 13. Avontuur & chardonnay & 70,63 & 3,5 & 3,5 & 84,70 & 81,19 & $-3,51$ \\
\hline 14. Cape Point Vineyards & sauvignon blanc & 80,06 & 3,5 & 4 & 72,13 & 68,10 & $-4,03$ \\
\hline 15. Hazendal & chenin blanc & 32,00 & 3,5 & 3,5 & 52,44 & 45,36 & $-7,08$ \\
\hline 16. Stellenzicht & shiraz & 120,10 & 3,5 & 4 & 107,04 & 97,75 & $-9,29$ \\
\hline 17. Graham Beck & sauvignon blanc & 62,58 & 3 & 3,5 & 59,54 & 47,76 & $-11,78$ \\
\hline 18. Porterville & pinotage & 44,75 & 1,0 & 3 & 58,79 & 45,85 & $-12,94$ \\
\hline 19. Nederburg straight cabs & cabernet sauvignon & 68,49 & 1,5 & 3 & 64,86 & 50,58 & $-14,28$ \\
\hline 20. Mulderbosch Barrel Fermented. & chardonnay & 155,00 & 4 & 4 & 98,43 & 81,19 & $-17,24$ \\
\hline 21. Eikendal & cabernet sauvignon & 81,50 & 3,0 & 3,5 & 83,88 & 66,55 & $-17,33$ \\
\hline 22. Glen Carlou Grand Classique & red blend & 120,00 & 4 & 4 & 119,61 & 100,36 & $-19,25$ \\
\hline 23. Morganhof straight reds & red blend & 49,15 & 3,0 & 3,5 & 99,11 & 78,91 & $-20,20$ \\
\hline 24. Raka reds blends & red blend & 72,08 & 3,0 & 3,5 & 99,11 & 78,91 & $-20,20$ \\
\hline 25. Rust en Vrede & red blend & 270,00 & 3,5 & 4 & 122,27 & 100,36 & $-21,91$ \\
\hline 26. Vergelegen Mill Race & red blend & 56,00 & 3,5 & 4 & 122,27 & 100,36 & $-21,91$ \\
\hline 27. Springfield & sauvignon blanc & 62,93 & 3,5 & 3,5 & 72,13 & 47,76 & $-24,37$ \\
\hline 28. Mooiplaas & sauvignon blanc & 46,85 & 3 & 3 & 59,54 & 31,78 & $-27,76$ \\
\hline 29. Bon Courage & sauvignon blanc & 32,00 & 3 & 2,5 & 59,54 & 31,11 & $-28,43$ \\
\hline 30. Diemesfontein & shiraz & 81,51 & 3,5 & 3,5 & 107,04 & 76,30 & $-30,74$ \\
\hline 31. Moreson "Pinehurst" & pinotage & 39,00 & 3,5 & 3,5 & 100,63 & 61,82 & $-38,81$ \\
\hline 32. Delheim & pinotage & 91,98 & 3,5 & 3,5 & 100,63 & 61,82 & $-38,81$ \\
\hline 33. Nederberg Private Bin & cabernet sauvignon & 80,00 & 3,5 & 3,5 & 107,04 & 66,55 & $-40,49$ \\
\hline 34. Glen Carlou Tortoise Hill & red blend & 40,00 & 3,5 & 3,5 & 122,27 & 78,91 & $-43,36$ \\
\hline 35. Kanu Limited Release Wooded & chenin blanc & 70,00 & 4,5 & 4 & 111,77 & 65,70 & $-46,07$ \\
\hline \multicolumn{2}{|l|}{ Mean } & 113,61 & 3,73 & 3,06 & 91,16 & 84,65 & $-6,51$ \\
\hline \multicolumn{2}{|l|}{ Standard Deviation } & 136,60 & 0,46 & 0,92 & 25,65 & 38,49 & 27,27 \\
\hline
\end{tabular}


3. Using the quality premium method, high brand values accrue either through large sighted-to-blind quality differentials, or through top-end wines yielding strong sighted and blind scores. With respect to the quality premium analysis, the largest brand premiums accrue to three of the flagship brands noted above. With respect to these three, (Ernie Els, Morganhof Premier Selection, and Vergelegen $V$; with brand premiums greater than R50 in each instance), we note two distinct characteristics, namely: (1) high intrinsic and exceptionally high sighted wine assessment scores, and (2) consequently marginal placebos. Under these conditions, one would intuit a corresponding preponderance of small brand premiums. This however is not the case. Large brand premiums accrue here because of (1) the marked non-ordinal pricing effects manifest at the top end of the perceived sighted quality spectrum, and (2) the substantially less accentuated non-ordinal valuation effects in the corresponding blind-based/intrinsic model valuations. Thus in the instance of the Ernie Els for example: the 4 star blind score is worth only R119,61. Its 4,5 star sighted score is, by comparison, worth substantially more: R174,58, hence the sizable quality brand premium of R54,97.

Conversely, where one would imagine the large brand premiums being awarded to large placebos (sighted minus blind scores) - this is not always the case. On the application of the non-ordinal valuation models, the largest placebos, (a difference of two stars between sighted and blind scores), serve up a mixture of qualitybased brand premium values, both negative (see Porterville pinotage $(-12,94)$ ) - and positive (see Diemersdal cabernet $(\mathrm{R} 1,69)$, Welgemeend red blend (R20,61), Bilton merlot (R24,34), Bouchard Finlayson Sans Barrique chardonnay (R22,23) and the Cabrière pinot noir (R20,84)).

While in the main, we observe that large quality differentials tend to drive strong brand valuations (four of the six above average over R20), at the top end of the quality spectrum, smaller placebos (such as those from Ernie Els and Vergelegen $V$ ) can prove just as valuable.

4. Using the price premium method, top-end quality red wines tend to dominate, with excessive valuations noted at price points above R250. With respect to the price premium analysis, at the top end we note once more that the largest brand premiums accrue to the flagship red brands: Vergelegen $V$ and the Ernie Els (priced at R730 and R500 respectively) - and also to R270 Rust en Vrede. However, unlike the quality premium analysis, where the top three brand premiums amount to a little over R50, here the average brand premium of these top three brands is a stellar R378,62. Thus in addition to the high intrinsic wine assessment scores and the marginal placebos associated with these wines, we note also their ultra-high prices, and the extent to which these appear to drive their substantial price premiums. (In contrast we observe in each instance the modest underpinning intrinsic value per bottle; which, for the three above cited premium wines, read at R122,27, R119,61 and R122,97, respectively.) The Vergelegen $V$ is the stand-out here, yielding a price premium of R607,73, 11 times the premium using the alternate method of calculation. Similarly, the Ernie Els yields a price premium of R380,39, almost seven times the size of the R54,97 derived from the quality premium method.

At the bottom end of 14 positive price premiums we note eight wines with price premiums under R25; five of which feature with premiums of less than R8. While clearly these eight wines present with cellar door prices slightly more than their intrinsic value, worth noting is that in the main, these are not poor wines: their average blind score is 2,93, well above the average 2,67 (with a standard deviation of 0,88.) Aside from the Bouchard Finlayson Sans Barrique Chardonnay and the Nederburg (straight) cabernet (both 1,5 stars blind), these are all wines worth drinking.

Moving to the negative brand premiums we note that the intrinsic quality of these wines increases further, with the lowest eight of the brand premiums averaging 3,43 stars blind. However the majority of these eight wines are all well under-priced relative to their intrinsic worth - with an average price of R53,52 versus an average intrinsic value of R102,72. In short, these wines constitute top value-for-money brands, which while important for consumers, constitute negative value for their holding companies. This is important to note: so-called "value-for-money" brands, in this study, carry negative valuations, and serve as an indication that their owners should increase their prices.

5. Though easier to compute, the price-premium method yields a more volatile set of results. The summative aspects of Tables 4 and 5 also align with the comparative valuation dynamics as noted above. For example we note that the mean for the price premium method is R28,96 higher than the quality premium style of analysis (respective means are R22,45 versus $\mathrm{R} 6,51)$. Due to the broad spread of prices relative to the derived quality-based valuations for wines, the price premium standard deviation is also larger: $\mathrm{R} 127,16$ compared to the far more modest R27,27 of the quality premium analysis. In the light of these figures we must consider whether price is a reasonable means by which to calculate the value of the brand. To its credit the price premium methodology implicitly acknowledges that it is the actual price-point at which a customer is willing to exchange currency for the wine in question and, hence, provides a more direct and perhaps more calibrated means to value a brand. This said, on two counts, the excessive nature of some prices do make this methodology problematic. Firstly, since the seller is welcome to charge whatever he or she sees fit, one should anticipate some degree of excessive pricing relative to the intrinsic value of the brand in question though only within the confines of supply and demand price dynamics. Excessive pricing cannot continue indefinitely, and may decay in future. Secondly, arbitrarily under-pricing a bottle may in turn lead to a situation where the generic value of the wine may in 
fact be greater than the price being asked for it. This will in turn result in negative brand premiums. Both extremes are empirically demonstrated in this study. Figures III and IV below provide comparative illustrations of the brand premium distribution as per the two methods of calculation.

By virtue of the excessive valuations noted in the price premium sample, we hold that so calculating a brand premium is perhaps less constrained and predictable than were we to calculate a premium by way of a wine's perceived sighted quality. Therefore, as opposed to the invocation of price, we note that quality-based valuations are thus more likely to register tighter, lower and less volatile estimates of brand premiums. Again, this is in line with the higher adjusted $\mathrm{R}^{2}$ figures attracted in the sighted valuation models as opposed to the lower ones in the blind models (see Table 3). Due to the lack of correlation between price and blind ratings, the error term $\left(\varepsilon_{\text {blind }}\right)$ that defines the pricemethod premium is simply that much larger and more volatile than the difference between the two error terms $\left(\varepsilon_{\text {blind }}-\varepsilon_{\text {sighted }}\right)$ that defines the quality-method premium.

\section{Final brand value computations}

Careful scrutiny of Tables 4 and 5 shows that six brands emerge with positive brand premiums on both metrics. These are the Ernie Els, the Vergelegen $V$, the Morganhof Premier Selection, the Cabrière pinot noir, the Bouchard Finlayson Sans Barrique chardonnay and the Bilton merlot. For purposes of comparison and with information on each of their annual volumes we can now compute their total brand value in terms of current and future cash flows, as per the two outlined methodologies.

Embedded within these calculations are the following assumptions:

- The brands in question will continue to deliver the consistent levels of blind and sight-based quality that marked them as brands in the first place.

- Controlling for inflation, volumes generated by each brand are all sold to the market at current prices. Price premiums are maintained going forward.

- Assuming hectorage to be a constant cap on further production, growth $(\mathrm{G})$ in each instance is pegged at zero.

- Final brand valuations for each method are thereby treated in the same vein as perpetuities, that is to say, with a stream of dividends running indefinitely into the future. Further in this study this fourth assumption is relaxed.

To restate, CAPM-related inputs employed in each calculation are as follows: (1) the risk free rate $\left(\mathrm{R}_{\mathrm{f}}\right)$ is
$8,00 \%$, (2) the equity risk premium $\left(\mathrm{R}_{\mathrm{m}}-\mathrm{R}_{\mathrm{f}}\right)$ is $5,50 \%$, and (3) the associated beta value is 0,815 . Volumes for Vergelegen $V$ and Ernie Els were sourced off the Wines of South Africa (WOSA) and the wineroute.com websites, respectively. The remaining four brand's volumes were volunteered by the marketing managers of each winery.

Reading off the final brand valuations as they appear in Table 6 below, we note that the price premium method realises an average valuation of R19,7 million, almost three times the R6,8 million average derived from the alternate method. The respective standard deviations (R19,9 million versus $\mathrm{R} 4,4$ million) are also reflective of inherent volatility of the price premium methodology.

Of the six brands presenting, by way of the volumes produced, and regardless of the methodology employed, the Ernie Els (with an annual volume of 1500 cases), is the most valuable. While per bottle, the quality brand premium of the Vergelegen $V$ is almost identical to that of the Ernie Els (R52,31 vs. R54,97), its limited annual production (500 cases versus that of the 1500 cases of Ernie Els) means that its total brand value of just over 2,5 million rands is proportionately fractional compared to the 7,9 million rands value of the Ernie Els brand.

Employing the alternate price premium method, we note how the value of these two premium brands becomes stratospheric. For example, the R500 Ernie Els would increase almost seven-fold in total brand value from R7,9 million to R54,8 million. By the same token, the Vergelegen $\mathrm{V}$ would increase more than 11 fold from 2,5 million to 29 million rands. By comparison, the valuations derived for the four remaining brands appear far less excessive, and in three of these (namely the Morganhof Premier Selection, the Bouchard Finlayson Sans Barrique chardonnay and the Bilton merlot) the quality premium method yields a figure greater than that derived from the price premium. Once more, we observe therefore how differences between the two methods develop at the extremities of each sample, and not at the centre.

The effect of time on earnings is also noteworthy. Were we to calculate their final NPV values based merely on five years earnings instead of infinity, we note how brand valuations remain at less than half the perpetuity value. Employing the price premium style of valuation, we note for example how the infinity-based Ernie Els brand valuation drops from 54,8 million rands to a mere 24,4 million rands based on just five years of brand premium cash flows. From Table 7 below we note too how pushing the valuation timeperiod out to ten and fifteen years, increases this figure to 37,9 and 45,5 million rands, respectively. These figures are far closer to the perpetuity-driven R54,8 million, and yet brief enough to account for boom-bust type scenarios typical of the wine industry (see Anderson, Norman \& Wittwer, 2001). 


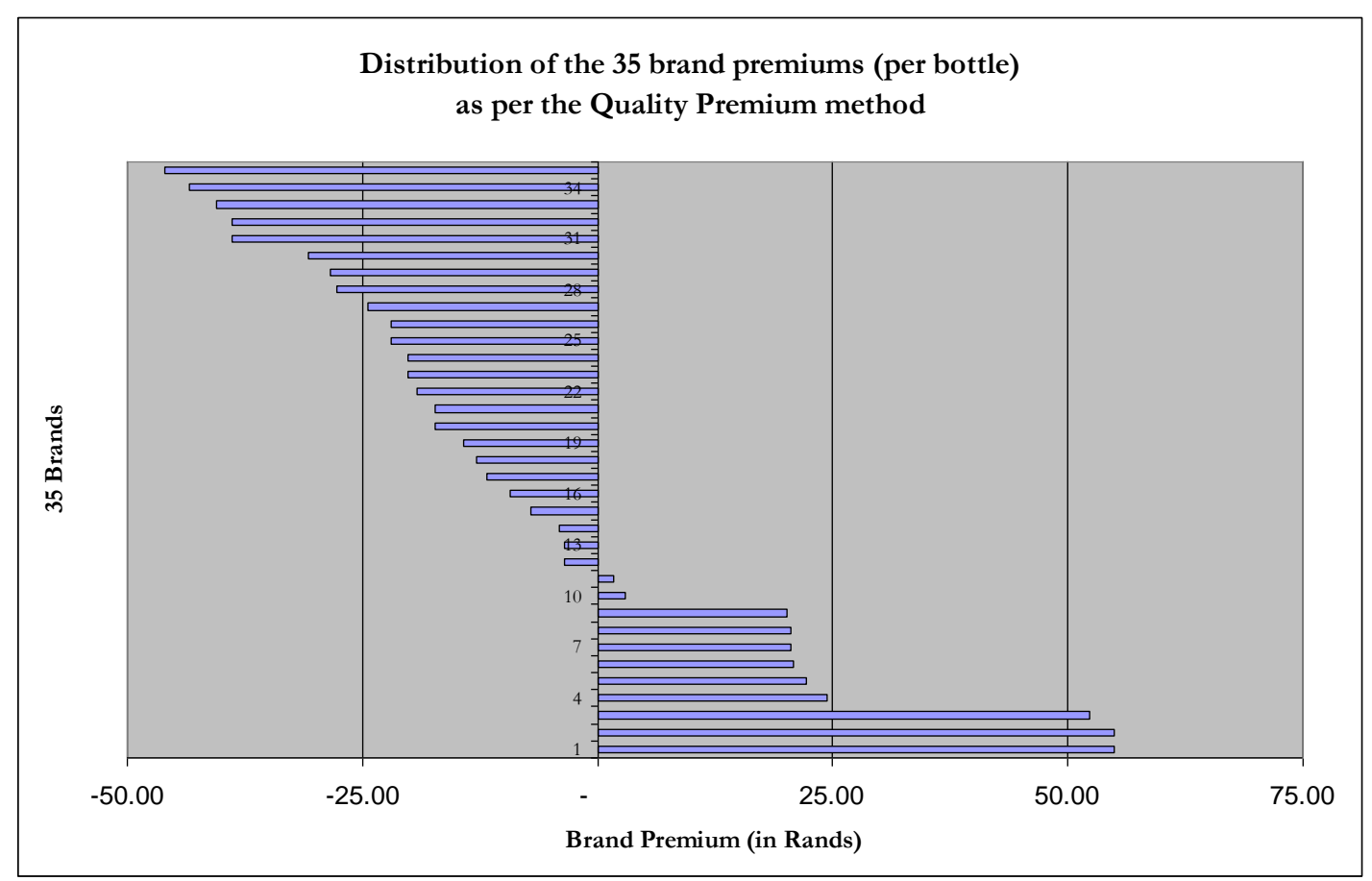

Figure 3: Brand premium distributions for the quality premium brand equity estimate. This we define as the difference between a bottle's intrinsic value and, instead of price, the value of its perceived quality when the wine is sampled sighted. (Figures in Rands as of 2007.)

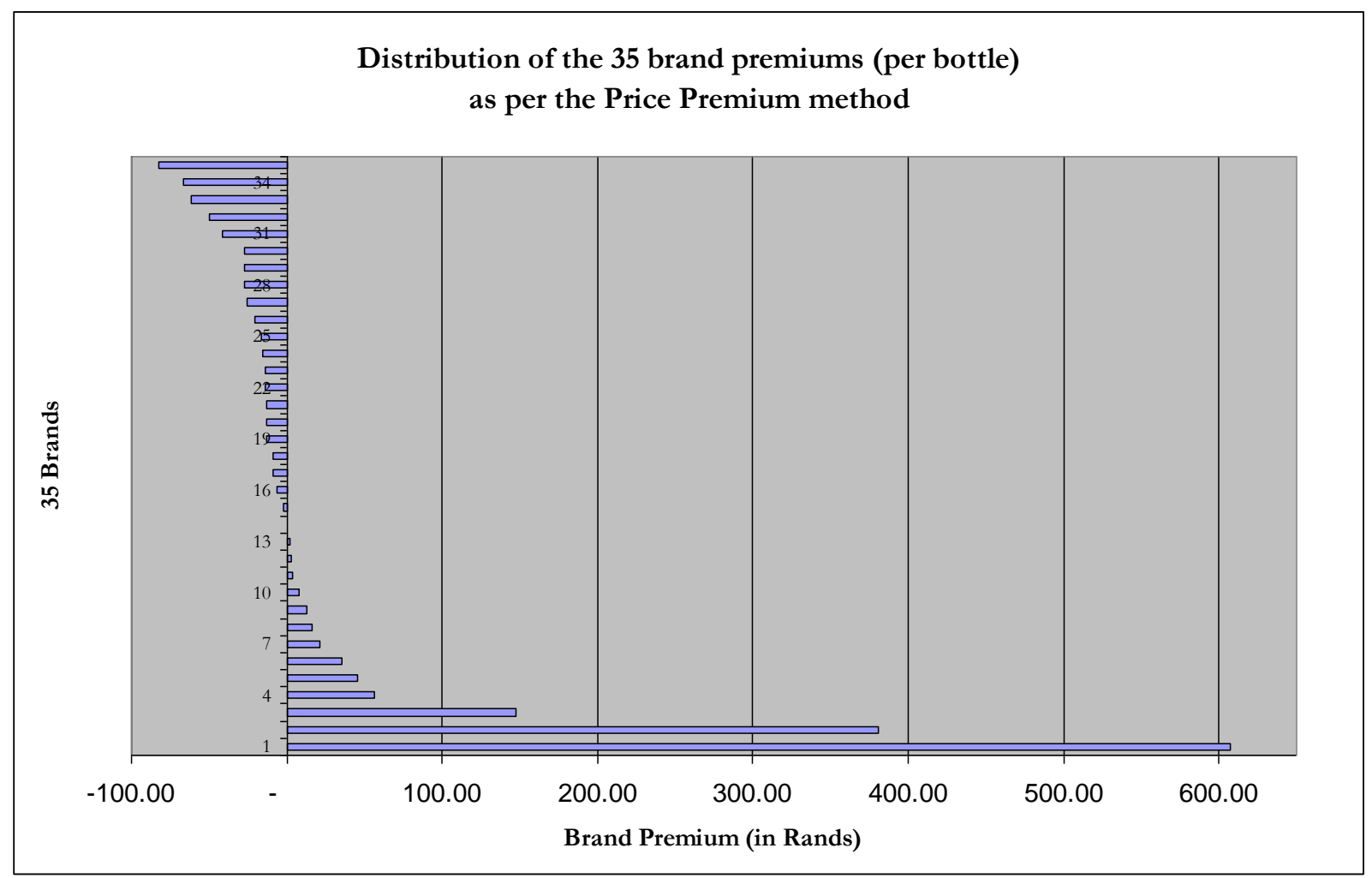

Figure 4: Brand premium distributions for the price premium brand equity estimate. This estimate of brand equity is defined as the difference between bottle price and a valuation of the bottle's intrinsic worth when tasted blind. This in effect, is the error term derived from the blind-based pricing model $\left(\varepsilon_{\text {blind }}\right)$, and explains why these valuations are so much more volatile than the $\left(\varepsilon_{\text {blind }}-\varepsilon_{\text {sighted }}\right)$ resolution of the quality premium method. (Figures in 2007 Rands.) 
Table 6: Final brand valuations for the six brands simultaneously positive in both brand premium methodologies. These are ranked by descending order of price premium brand values (final column). (All Rand figures cited as of 2007.)

\begin{tabular}{|c|c|c|c|c|c|c|}
\hline Brand & $\begin{array}{l}2007 \\
\text { Price }\end{array}$ & $\begin{array}{l}\text { Quality Brand } \\
\text { Premium per } \\
\text { unit (in Rands) }\end{array}$ & $\begin{array}{c}\text { Price } \\
\text { Brand Premium } \\
\text { per unit (in } \\
\text { Rands) }\end{array}$ & $\begin{array}{l}\text { 12-bottle } \\
\text { cases } \\
\text { p.a. }\end{array}$ & $\begin{array}{l}\text { Quality Premium } \\
\text { brand value (in } \\
\text { Rand millions) }\end{array}$ & $\begin{array}{l}\text { Price Premium } \\
\text { brand value (in } \\
\text { Rand millions) }\end{array}$ \\
\hline $\begin{array}{l}\text { Ernie Els Wines } \\
\text { (red blend) }\end{array}$ & 500,00 & 54,97 & 380,39 & 1500 & 7,927 & 54,853 \\
\hline $\begin{array}{l}\text { Vergelegen } V \\
\text { (red blend) }\end{array}$ & 730,00 & 52,31 & 607,73 & 500 & 2,514 & 29,212 \\
\hline $\begin{array}{c}\text { Cabrière } \\
\text { (pinot noir) }\end{array}$ & 128,29 & 20,84 & 35,59 & 5000 & 10,017 & 17,107 \\
\hline $\begin{array}{c}\text { Morgenhof Premier Selection } \\
\text { (red blend) }\end{array}$ & 165,00 & 54,97 & 45,39 & 2500 & 13,211 & 10,909 \\
\hline $\begin{array}{l}\text { Bouchard Finlayson Sans Barrique } \\
\text { (chardonnay) }\end{array}$ & 80,00 & 22,23 & 21,04 & 2300 & 4,915 & 4,652 \\
\hline $\begin{array}{c}\text { Bilton } \\
(\text { merlot })\end{array}$ & 80,80 & 24,34 & 16,29 & 833 & 1,949 & 1,305 \\
\hline Mean & 280,68 & 38,28 & 184,41 & $2,105,50$ & 6,756 & 19,673 \\
\hline Standard deviation & 270,86 & 17,38 & 250,61 & $1,620,81$ & 4,431 & 19,875 \\
\hline
\end{tabular}

Table 7: How the time period for the NPV calculation affects the final brand valuations. (All Rand figures as of 2007.)

\begin{tabular}{|c|c|c|c|c|c|c|c|c|c|c|}
\hline \multirow[t]{2}{*}{ BRANDS } & \multicolumn{5}{|c|}{ Quality Premium Valuations (in R 1000 units) } & \multicolumn{5}{|c|}{ Price Premium Valuations (in $R 1000$ units) } \\
\hline & 5 yrs & 10 yrs & 15 yrs & $20 \mathrm{yrs}$ & infinity & $5 \mathrm{yrs}$ & 10 yrs & 15 yrs & 20 yrs & infinity \\
\hline $\begin{array}{l}\text { Ernie Els Wines } \\
\text { (red blend) }\end{array}$ & 3,525 & 5,482 & 6,569 & 7,307 & 7,927 & 24,390 & 37,935 & 45,457 & 50,562 & 54,853 \\
\hline $\begin{array}{l}\text { Vergelegen } V \\
\text { (red blend) }\end{array}$ & 1,118 & 1,739 & 2,084 & 2,318 & 2,514 & 12,989 & 20,202 & 24,208 & 26,927 & 29,212 \\
\hline $\begin{array}{c}\text { Cabrière } \\
\text { (pinot noir) }\end{array}$ & 4,454 & 6,928 & 8,301 & 9,234 & 10,017 & 7,607 & 11,831 & 14,177 & 15,769 & 17,107 \\
\hline $\begin{array}{c}\text { Morgenhof Premier Selection } \\
\text { (red blend) }\end{array}$ & 5,874 & 9,136 & 10,948 & 12,178 & 13,211 & 4,851 & 7,544 & 9,040 & 10,055 & 10,909 \\
\hline $\begin{array}{l}\text { Bouchard Finlayson Sans Barrique } \\
\text { (chardonnay) }\end{array}$ & 2,186 & 3,400 & 4,073 & 4,531 & 4,915 & 2,069 & 3,217 & 3,855 & 4,288 & 4,652 \\
\hline $\begin{array}{c}\text { Bilton } \\
(\text { merlot })\end{array}$ & 867 & 1,348 & 1,615 & 1,797 & 1,949 & 580 & 902 & 1,081 & 1,202 & 1,304 \\
\hline Mean & 3,004 & 4,672 & 5,599 & 6,227 & 6,756 & 8,747 & 13,605 & 16,303 & 18,134 & 19,673 \\
\hline Standard deviation & 1,970 & 3,064 & 3,672 & 4,084 & 4,431 & 8,837 & 13,745 & 16,471 & 18,320 & 19,875 \\
\hline
\end{tabular}

\section{Conclusion}

Through the deployment of hedonic and DCF theory, this empirical analysis sought to establish a means by which wine brands could be valued. Here a dummy-style approach to price modelling was employed as part of a synthesised technique to value the wine brands identified in Priilaid and Van Rensburg (2010a). In so doing, two wine brand valuation techniques were identified and contrasted. In conjunction with conventional net-present-value style (NPV) company valuation methods, these techniques are founded on the use of the non-ordinal wine valuation models developed in Priilaid and Van Rensburg (2010b).

Based on a wine's price premium, the first of these techniques specifies brand equity per bottle as the difference between a wine's price and a valuation of its intrinsic worth. Such valuations are derived from scores of blind-based wine tastings and do not contain any extrinsic bias. A product's price premium, commonly regarded as a measure of the extent to which a consumer is willing to pay for a product over and above its intrinsic value, can thus be held as a measure of consumer loyalty. The second technique specifies brand equity as the difference between intrinsic value and, instead of price, the value of a wine's perceived quality on sighted assessment. Though somewhat coarser than the former technique, a valuation of this form can also serve as a proxy for consumer preference when contrasted with the valuation of a generic wine product of similar quality.

By valuing both versions of brand equity, this analysis considered the degree to which a branded wine is trading over and above its value merely as a non-specified bottle of similar quality. In doing so, it noted that symbolic brands can only be valued when presenting concurrently as functional brands that is to say, with consistently determinable levels of intrinsic quality. In the process of valuing 35 wine brands that conform to this specification the 
two brand valuation methodologies were deployed and contrasted.

Invoking the quality premium method, positive intermediate valuations were noted in 11 out of the 35 brands. Six of these are red blends; four flagship brands. The widest difference between sighted and blind valuations accrued to top quality red wines at just over R50 per bottle.

In contrast 14 positive intermediate valuations were noted using the price premium approach. Again six of these are red blend "flagship" brands. Extreme valuations are observed at both ends of the price premium sample, the largest being calculated at over R600 for a bottle of Vergelegen $V$. Contrasted to the quality premium-based valuations, this volatility is entirely expected; the price premium method equating to no more than the error term of its blind valuation. Devoid of any price-cue bias, such errors are likely to be far larger than those derived from sighted valuations. Inevitably therefore, the price premium method is the less conservative and hence more unpredictable of the two.

On computing the full NPV value of the six brands with positive brand premiums, a price premium mean valuation of R19,7 million is noted. This is three times greater than the average derived from the quality premium technique. The respective standard deviations are also reflective of the inherent volatility of the price premium approach. In both instances the stricture of perpetuity is perhaps too excessive for sensible valuations. By comparison, a ten-year time horizon yields brand asset values roughly seventy per cent of the size. Time periods of this order are probably more accommodating of the cyclical nature of the wine industry.

\section{Significance of findings}

1. In the instances in which brand effects are legitimately identified, this study enables their valuation. It is, however, worth noting that candidate brands were only considered for valuation if they presented with a minimum sixyear period of assessment. This specification is arbitrary and could in future be reduced to three, four or five years. One can speculate that, under such conditions, more symbolic and functional brand effects are likely to be identified. This being so, subsequent brand valuations should also be tied, or at least, correlated to the period of their statistical consistency. A brand that presents with three years of stable quality can certainly not expect valuations based on earnings excessively beyond such a period. Industry debate as to an appropriate period of brand gestation is anticipated.

2. This technique now provides brand-owning producers with a route to determine the value of their firms and thus improve their consequent ability to raise company loans. More so, with the means developed to identify valid symbolic and functional brand effects (Priilaid \& Van Rensburg 2010), appropriate milestones for the development of brands can now be laid down along with the attendant strategies for their attainment. While this will enable the setting of industry standards, a word of warning is appropriate. On two counts this study notes that functional brands are easier to value than symbolic ones. Firstly, there are more of them ${ }^{4}$ and, secondly, their valuation by way of the more volatile price premium technique requires no attached condition of placebo. Sight-based valuation models are hence not required. Such ease of execution could precipitate industry practice defaulting to this lesser species of valuation. With such practice the risk exists that consequent brand values are equated to those of symbolic placebos. Such brand class conflation should be closely monitored. Functional brands are the lesser evolved cousins of symbolic brands.

3. At a broad level, this study's application of hedonic pricing to the valuing of wine brands demonstrates a means by which a consumer-perspective can be applied ably within the traditionally companyfacing discipline of financial accounting.

\section{Limitations and future research}

With sufficient historical data we could anticipate a valuation study modelling the potential for brand-premium decay over time. What rate of decay is appropriate - and how should this rate then be gauged? Answers to such questions would provide a meaningful contribution to the existing literature. Clearly, as our methods of brand valuation develop, so too must the depth of our qualitybased datasets. While the 2000 to 2007 database used to identify and value the brands in this study has served as a fertile statistical source, it remains to be expanded.

Given the appropriate modelling techniques and the availability of finance related metrics, this study demonstrates that these assets are not difficult to evaluate. What is difficult however is the development of wines that can, over time, ably present with consistent levels of quality both intrinsically and sighted. It is upon these variated forms of consistency that such wines can manifest, ultimately, as brands, and this can only occur through careful management in vineyard, cellar and the marketplace.

\section{References}

Aaker, D. 1996. 'Measuring brand equity across products and markets', California Management Review Spring: 102120.

Anderson, K., Norman, D. \& Wittwer, G. 2001. Globalization and the world's wine markets: Overview. Discussion Paper No. 0143 November, Adelaide University.

Anon. 2009. 'Ernie Els cases produced'. [online] URL: http://www.thewineroute.com.sg/home/index.php?pg=wine_ details\&wid=15. Accessed 29 September 2009.

${ }^{4}$ In Priilaid and Van Rensburg (2010a) functional brands outnumbered their symbolic counterparts by 148 to 72 . 
Anon. 2009. 'Vergelegen $V$ cases produced'. [online] URL: http://www.wosa.se/news_article.php?id=1026. Accessed 29 September 2009.

Barth, M. E., Clement, M. B., Foster, G. \& Kasznik, R. 1998. 'Brand values and capital market valuation', Review of Accounting Studies, 3: 41-68.

Brealey, R. A. \& Meyers, S. C. 2000. Principles of corporate finance, $6^{\text {th }}$ Edition. London: Irwin McGraw Hill.

Chitturi, R., Raghunathan, R. \& Mahajan, V. 2008. 'Delight by design: The role of hedonic versus utilitarian benefits', Journal of Marketing, 72(May): 48-63.

Colvin, G. 2008. Talent is overrated - What really separates world-class performers from everybody else. London: Nicholas Brealey Publishers.

Coombris, P., Lecocq, S. \& Visser, M. 1997. 'Estimation for a hedonic price equation for Bordeaux wine: Does quality matter?', The Economic Journal, 107(441): 390-402.

Damodaran, A. 2006. Damodaran on valuation - Security analysis for investment and corporate finance, $2^{\text {nd }}$ Edition. Hoboken, New Jersey: John Wiley \& Sons.

Erdem, T. \& Swait, J. 1998. 'Brand equity as a signaling phenomenon', Journal of Consumer Psychology, 7(2): 131157.

Fernandez, P. 2001. 'Valuation of brands and intellectual capital.' Working Paper, IESE Business School, University of Navara, Madrid, Spain. [online URL: http://papers.ssrn.com/sol3/papers.cfm?abstract_id=270688. Accessed 12 July 2010.

Firer, C. \& Staunton, M. 2002. '102 years of South African financial market history', Investment Analysts Journal, 56(5): 57-65.

Gerzema, J. \& Lebar, E. 2008. The brand bubble -The looming crisis in brand value and how to avoid it. San Francisco: Jossey Bass Publishers.

Gordon, M.J. \& Shapiro, E. 1956. 'Capital equipment analysis: The required rate of profit', Management Science, 3(1): 102-110.

Kamakura, W. A. \& Russell, G. J. 1993. 'Measuring brand value with scanner data', International Journal of Research Marketing, 10: 9-21.

Keller, K.L. 1993. 'Conceptualizing, measuring and managing customer-based brand equity', Journal of Marketing, 57: 1-22.

Keller, K.L. 2003. Strategic brand management: Building, measuring and managing customer-based brand equity. Upper Saddle River, New Jersey: Pearson Education Inc.
Lev, B. 2003. 'Remarks on the measurement, valuation and reporting of intangible assets', FRBNY Economic Policy Review, September: 17-22.

Lev, B. \& Zarowin, P. 1999. 'The boundaries of financial reporting of intangible assets and how to extend them', Journal of Accounting Research, Autumn: 353-385.

Lintner, J. 1965. 'The valuation of risk assets and the selection of risky investments in stock portfolios and capital budgets', Journal of Economics and Statistics, 47: 13-37.

Mowle, J. \& Merrilees, B. 2005. 'A functional and symbolic perspective to branding Australian SME wineries', Journal of Product and Brand Management, 14(4): 220-227.

National Energy Regulator of South Africa. 2008. 'Risk-free rate, inflation and cost of equity data with market return and market risk premium calculations - updated on 19 November 2008'. [online] URL:

http://www.nersa.org.za/Admin/Document/Editor/file/Petrol eumPipelines/Tariffs/NERSA\%20STORAGE\%20TARIFF \%20PRESENTATION\%20short.pdf. Accessed 12 Sep 2010.

Nerlove, M. 1995. 'Hedonic price functions and the measurement of preferences: The case of Swedish wine consumers', European Economic Review, 39(9): 1697-1716.

Oldert, N. (Ed.). 2007. Profile's Stock Exchange Handbook: June 2007 - September 2007. Johannesburg: Profile Media.

Oczkowski, E. 1994. 'A hedonic price function for Australian premium table wine', European Journal of Agricultural Economics, 38: 93-110.

Park, C.S. \& Srinivasan, V. 1994. 'A survey-based method for measuring and understanding brand equity and extendibility', Journal of Marketing Research, 31: 271-288.

Priilaid, D. \& van Rensburg, P. 2006. 'Non-linearity in the hedonic pricing of South African red wines', International Journal of Wine Marketing, 18(3): 166-182.

Priilaid, D. \& Van Rensburg, P. 2010a. 'Symbolic and functional brand effects in the hedonic assessment of South African wines', South African Journal of Business Management, 41(3): 15-38.

Priilaid, D. \& Van Rensburg, P. 2010b. 'The use of hedonic pricing in the valuation of South African wines.' In Proceedings of the $22^{\text {nd }}$ Conference of the South African Institute of Management Scientists, Grahamstown, 12-15 September 2010.

Schamel, G. 2000. Individual and collective reputation indicators of wine quality. CIES Discussion Paper 0009, Centre for International Economic Studies, University of Adelaide.

Schamel, G. \& Anderson, K. 2001. 'Wine quality and varietal, regional, and winery reputations: Hedonic prices for Australia and New Zealand'. CIES Workshop Paper 20, 
Centre for International Economic Studies, University of Adelaide.

Sharpe, W. F. 1964. 'Capital asset prices: A theory of market equilibrium under conditions of risk', Journal of Finance, 19: 425-442.

Srinivasan, V. 1979. 'Network models for estimating brandspecific effects in multi-attribute marketing models', Management Science, 25 (January): 11-21.

Swait, J., Erdem, T., Louviere, J. \& Dubelaar 1993. 'The equalization price: A measure of consumer-perceived brand equity', International Journal of Research in Marketing, 10(3): 23-45.

Thrane, C. 2004. 'In defence of the price hedonic model in wine research', Journal of Wine Research 15: 123-134.

Van Rensburg, P. \& Priilaid, D. 2004. 'An econometric model for identifying value in South African red wine', International Journal of Wine Marketing, 16(1): 37-53. 